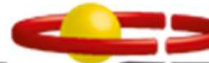 \\ UnIC=UB \\ Centro Unıversitárıo de Brasílıa \\ CENTRO UNIVERSITÁRIO DE BRASÍLIA - UnICEUB \\ PROGRAMA DE INICIAÇÃO CIENTÍFICA
}

VANESSA GAMA PACHECO BATISTA

A MORTE DO RIO DOCE, ESTADOS DE MINAS GERAIS E ESPÍRITO SANTO, COMO ECOCÍDIO BRASILEIRO NA NOVA CONCEPÇÃO DE CRIME INTERNACIONAL CONTRA A HUMANIDADE: UTOPIA OU REALIDADE?

BRASÍLIA

2018 


\section{$2=$ \\ Unic=Us \\ Centro Unıversıtárıo de Brasílıa}

VANESSA GAMA PACHECO BATISTA

A MORTE DO RIO DOCE, ESTADOS DE MINAS GERAIS E ESPÍRITO SANTO, COMO ECOCÍDIO BRASILEIRO NA NOVA CONCEPÇÃO DE CRIME INTERNACIONAL CONTRA A HUMANIDADE: UTOPIA OU REALIDADE?

Relatório final de pesquisa de Iniciação Científica apresentado à Assessoria de Pós-Graduação e Pesquisa.

Orientação: André Pires Gontijo

BRASÍLIA 
"Todas as flores do futuro estão contidas nas sementes de hoje." (Proverbio Chinês) 


\title{
A MORTE DO RIO DOCE, ESTADOS DE MINAS GERAIS E ESPÍRITO SANTO, COMO ECOCÍDIO BRASILEIRO NA NOVA CONCEPÇÃO DE CRIME INTERNACIONAL CONTRA A HUMANIDADE: UTOPIA OU REALIDADE?
}

\author{
Vanessa Gama Pacheco Batista - UniCEUB, PIC voluntário \\ vanessa.batista@sempreceub.com
}

\author{
André Gontijo - UniCEUB, professor orientador \\ andre.gontijo@ceub.edu.br
}

É desafiador reconhecer os direitos da natureza e do ecossistema, onde o homem deixaria de ser o "dono" da vida sobre a Terra, e passaria, a partir dessa ideia, a gerar uma nova concepção do direito, onde esse mesmo homem seria interdependente de outras espécies e do ecossistema. Destarte, como objetivo da pesquisa, identificar os principais motivos que remetem a impunidade das maiores atrocidades mundiais causadas pelo homem - como o crime de guerra, o genocídio, a agressão entre países e os crimes contra a humanidade, que não acompanham o avanço da ciência e do conhecimento - é crucial para se estabelecer um entendimento de um desenvolvimento, ainda, desenfreado em relação à sustentabilidade, à vida futura do planeta. No final de 2016, o Tribunal Penal Internacional - TPI, reconheceu a "possibilidade" da prática de Ecocídio como um novo delito, no quinto dispositivo do Estatuto de Roma, ao conferir especial atenção a crimes relacionados à "destruição do meio ambiente, à exploração de recursos naturais e à apropriação ilegal de terras". A partir desta realidade, o problema de pesquisa teve o intuito de responder se os crimes ambientais - como os ocorridos no Rio Doce, Estados de Minas Gerais e Espírito Santo - podem ser enquadrados na categoria de Ecocídio diante do TPI, diante da nova concepção de crime internacional contra a humanidade como uma utopia ou uma realidade. A hipótese da pesquisa considera que o ecossistema, ao qual se inclui a espécie humana, carece de uma vivência jurídica punitiva eficiente, que não se limita ao "ressarcimento monetário" por violação moral ou econômica e a "reparação" do ambiente afetado pelo dano, mas sim a responsabilização direta dos responsáveis com penas de prisão real, independente de quem o seja, isto é, empresas ou chefes de Estado e autoridades. Como metodologia, a pesquisa dogmático-instrumental, com alicerce em textos normativos, doutrina e estudo de precedentes, foi utilizada para a confecção da pesquisa. Foi preciso compreender primeiramente o próprio conceito de Ecocídio difundido no mundo e no Brasil, por meio de um levantamento bibliográfico, o qual foi realizado a partir da doutrina e da jurisprudência brasileiras, bem como em artigos científicos nas revistas jurídicas internacionais - com conceito " $\mathrm{A} 1$ ". Dentro dos resultados da pesquisa, esta foi dividida em três fases. A primeira, referente a pesquisa bibliográfica na doutrina e jurisprudência, sobre Ecocídio como um crime contra a humanidade; a segunda, uma pesquisa na doutrina e jurisprudência sobre o papel do TPI como guardião universal dos direitos humanos e do meio ambiente no âmbito internacional; e a terceira, o levantamento científico utilizando como ferramenta de pesquisa a plataforma sucupira, que traz em seu banco de dados, todas as revistas internacionais de direito no mundo. Como conclusão, foi possível responder se a "morte" do Rio Doce, localizado Estados de Minas Gerais e Espírito Santo, pode ser considerada um Ecocídio pelo TPI, ao compreender os reflexos da interpretação do TPI diante do Decreto n. 4.388, de 25/9/2002, que promulgou o Estatuto de Roma do TPI na ordem jurídico-ambiental brasileira.

Palavras-Chave: Direito Ambiental. Direito Internacional. Ecocídio. Rio Doce. 


\section{LISTA DE FIGURAS}

Figura 1: Cronologia da passagem do rejeito de minério de ferro desde o rompimento da barragem até o Oceano Atlântico. Fonte: Companhia de Pesquisa de Recursos Minerais (CPRM), 2016

.46

Figura 2: Pesquisa Científica sobre Ecocídio no Mundo entre 1972 a 2018 (Quali A1) na

Plataforma Sucupira. Fonte: autora, em 26/02/2018. 56 


\section{SUMÁRIO}

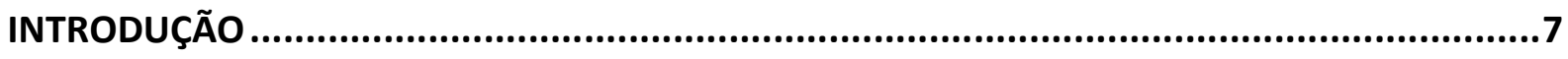

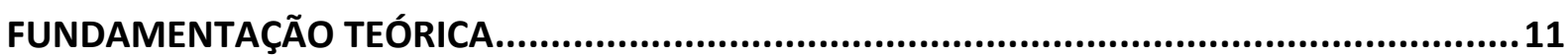

1. Direito Internacional do Meio Ambiente: histórico, princípios e normas basilares .....................13

1.1. Histórico do Direito Internacional do Meio Ambiente ........................................14

1.1.1. Princípios do Direito Internacional do Meio Ambiente ................................................... 15

1.1.2. Normas basilares do Direito Internacional do Meio Ambiente......................................... 16

1.2. Danos Ambientais e Ecológicos: responsabilidade e reparação internacional .....................23

1.3. Direitos Humanos e o Meio Ambiente ....................................................................... 23

1.4. O ecocídio como crime contra a humanidade: conceito, breve histórico e expectativas

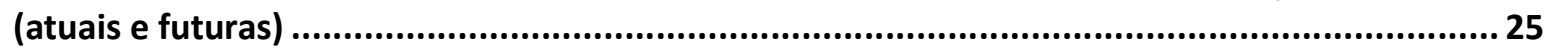

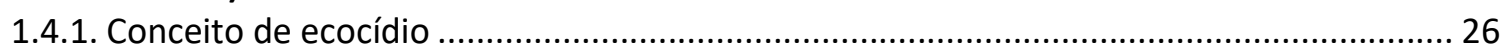

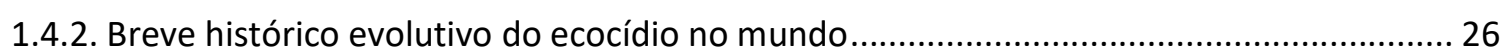

1.4.3. Breve histórico evolutivo do ecocídio como uma responsabilidade do Estado................. 27

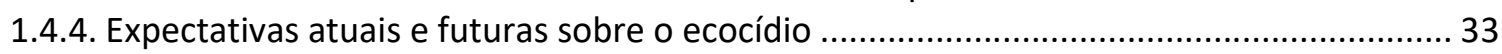

2. O Tribunal Penal Internacional como guardião universal dos direitos humanos e do meio

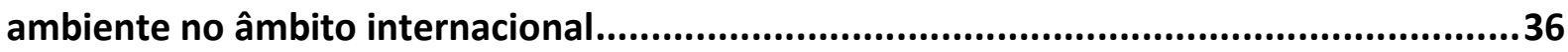

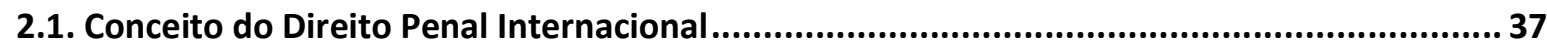

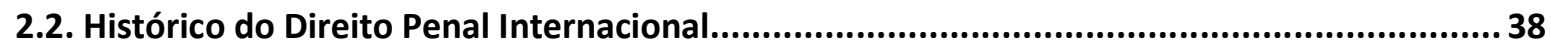

2.3. O Tribunal Penal Internacional: potencial guardião da proteção universal dos direitos

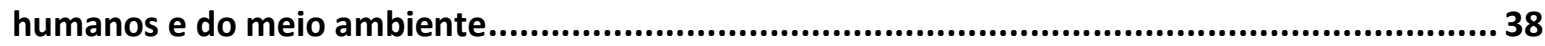

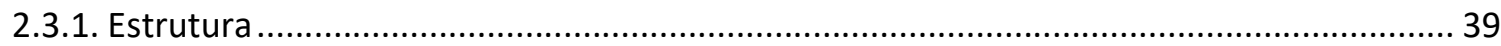

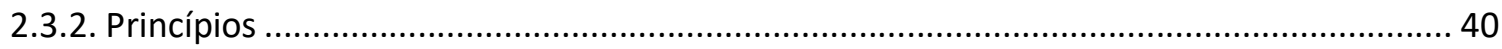

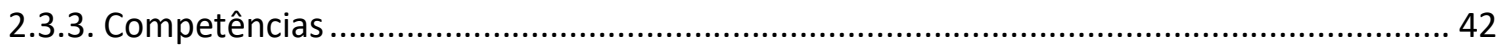

3. A morte do rio Doce, Estados de Minas Gerais e Espírito Santo, como ecocídio brasileiro

3.1. A tutela jurídica do meio ambiente e o papel dos órgãos de fiscalização e de controle

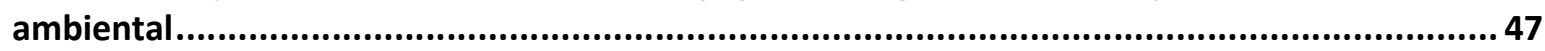

4. Ecocídio no Brasil: o estudo de caso na nova concepção de crime internacional contra a

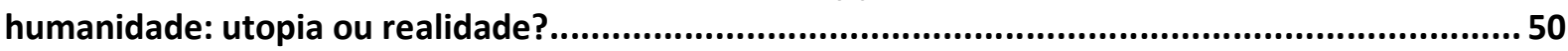

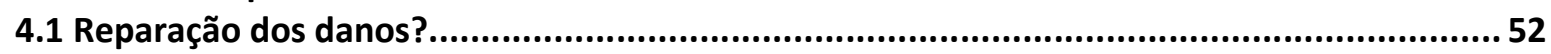

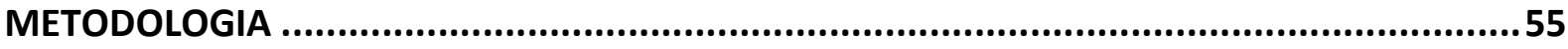

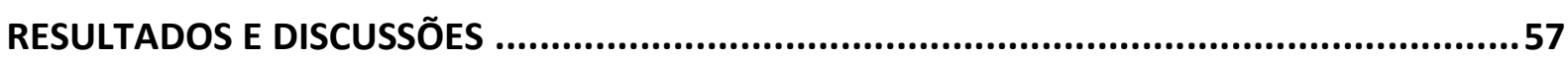

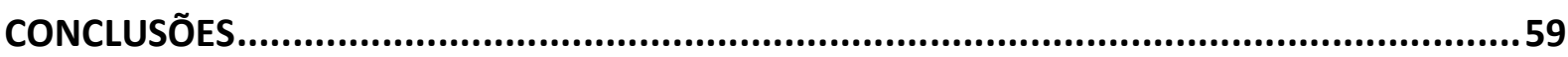

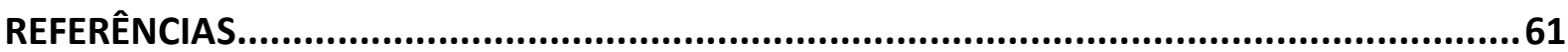




\section{INTRODUÇÃO}

Reconhecer os direitos da natureza e do ecossistema, onde o homem deixaria de ser o "dono" da vida sobre a Terra, e passaria, a partir dessa ideia, gerar uma nova concepção do direito, onde esse mesmo homem seria interdependente de outras espécies e do ecossistema é desafiador.

Compreender os motivos que remetem a impunidade das maiores atrocidades mundiais causadas pelo homem, como: o crime de guerra, o genocídio, a agressão entre países e os crimes contra a humanidade, que não acompanham o avanço da ciência e do conhecimento são cruciais para se estabelecer um entendimento de um desenvolvimento, ainda, desenfreado em relação à sustentabilidade, isto é, à vida futura do planeta.

O ecossistema, ao qual se inclui a espécie humana, carece de uma vivência jurídica punitiva eficiente, que não se limitem ao "ressarcimento monetário" por violação moral ou econômica e a "reparação" do ambiente afetado pelo dano, mas sim a responsabilização direta dos responsáveis com penas de prisão real seja empresas ou chefes de Estado e autoridades, sem distinção.

Em 15 de setembro de 2016, a mais alta corte da Organização das Nações Unidas, o Tribunal Penal Internacional (TPI), reconheceu a "possibilidade" da prática de ecocídio (termo que designa a destruição em larga escala do meio ambiente) como um novo delito, no quinto dispositivo do Estatuto de Roma, ao passar a "dar" especial atenção a crimes relacionados à "destruição do meio ambiente, à exploração de recursos naturais e à apropriação ilegal de terras".

O significado desta "possibilidade", em outras palavras, é o de interpretar este tipo de crime de maneira mais ampla, incluindo os crimes contra o meio ambiente, passando a considerar os crimes que venham a impactar as condições de existência de uma população por destruição do ecossistema, como no caso de desmatamento, mineração irresponsável, grilagem de terras e exploração ilícita de recursos naturais, entre outros.

No contexto brasileiro, considerando que o país é signatário do Estatuto de Roma (o qual instituiu o TIP) desde 10 de setembro de 2002 (uma vez que este entrou em vigor internacionalmente em 10 de julho de 2002), nos termos do seu próprio art. 126 - em texto aprovado pelo Congresso Nacional por meio do Decreto Legislativo no 112, de 06 de junho de 
2002 e pela sua promulgação com o Decreto no 4.388, de 25 de setembro de 2002 - sua previsão foi acrescentada como Direito e Garantias Fundamentais no §4으 do artigo 5ㅇ da Constituição da República Federativa do Brasil em 2004, pela Emenda Constitucional no 45.

De modo objeto, a partir de então, os crimes ambientais ocorridos no Brasil pelo homem, se comprovados como ecocídio, poderão ser julgados pelo TPI, sendo este um órgão de proteção do meio ambiente no juízo penal internacional.

O que implica nessa nova concepção de crime internacional contra a humanidade é se um terço dos membros do tratado, no mínimo, permitirão a real aplicabilidade dessa ferramenta de proteção ao meio ambiente ou se será apenas uma utopia, sendo mais um "instrumento meio" sem efetividade de aplicação, do que uma realidade mundial, não apenas brasileira.

Neste contexto, a pesquisa justifica-se por viabilizar um estudo voltado para analisar um exemplo de ecocídio brasileiro, na nova concepção de crime internacional contra a humanidade, tendo como estudo de caso o maior, e até a presente data, o mais impune de todos os tempos: "a morte do rio Doce", localizado nos Estados de Minas Gerais e Espírito Santo.

A morte do rio Doce, decorreu do rompimento da barragem "Fundão" da mineradora brasileira SAMARCO S/A, controlada através de um joint-venture entre a empresa Vale S.A. e a empresa anglo-australiana BHP Billiton, ocorreu no dia 05 de novembro de 2015 , no distrito de Bento Rodrigues, Município de Mariana no Estado de Minas Gerais. A tragédia, foi considerada um tsunami de 62 milhões de metros cúbicos de lama que "ecocidou" o distrito de Bento Rodrigues e outros sete distritos de Mariana, contaminando os rios Gualaxo do Norte e Carmo, entrando no curso do Rio Doce (este último objeto desta pesquisa), onde percorreu cerca de $680 \mathrm{~km}$ até sua foz em Linhares no Estado do Espírito Santo, até chegar ao oceano Atlântico.

Diante de todo o exposto, ao se reconhecer o ecocídio como crime contra a humanidade, há que se reconhecer os deveres da sociedade atual e das gerações futuras. Embora já seja claro que hoje exista um arcabouço penal e ambiental relevante, o Brasil ainda carece de um marco regulatório à altura da grandeza do seu meio ambiente, que requer proteção sólida frente as ações e decisões voltadas para o "lucro" das grandes empresas, e da 
irresponsabilidade dos entes da federação - como a União os Estados, o Distrito Federal e os Municípios - ao licenciarem atividades com potencial poluidor degradador sem uma fiscalização adequada.

Com a possibilidade de ecocídios ocorridos no país poderem ser considerados como crime contra a humanidade, a partir da identificação destes e de sua comprovação no TPI, não apenas as vítimas desses crimes assombrosos, mas os atores presentes na sociedade brasileira - e porque não os atores que compõem o ecossistema geral do planeta - poderão recorrer internacionalmente para obrigar os autores a pagarem não apenas danos morais ou econômicos em decorrência de suas ações, mas sim, e principalmente, a sua responsabilização direta, com sanções penais direcionadas a indivíduos determinados.

O objetivo geral a ser alcançado por meio desta pesquisa se concentra em responder se "o crime ambiental ocorrido no rio Doce, Estados de Minas Gerais e Espírito Santo, pode ser enquadrado na categoria de ecocídio diante do TPI, em virtude da nova concepção de crime internacional contra a humanidade?".

Como objetivos específicos, buscar-se-á:

a) identificar se a morte do rio doce, Estados de Minas Gerais e Espírito Santo pode ser identificado como crime ambiental provocado pela ação humana;

b) analisar se a morte do rio doce, Estados de Minas Gerais e Espírito Santo, pode ser enquadrado como ecocídio pelo TPI;

c) examinar os reflexos da mudança ocorrida ao final de 2016, com inclusão do ecocídio como crime contra a humanidade e sua interpretação diante do Decreto n. 4.388 , de 25/9/2002, que promulgou o Estatuto de Roma do TPI na ordem jurídica brasileira;

d) apontar se a morte do rio doce, Estados de Minas Gerais e Espírito Santo, se identificado como ecocídio, podem ser levados ao TPI e qual o procedimento a ser seguido à luz do princípio do desenvolvimento sustentável, bem como as repercussões desta análise na ordem jurídicoambiental brasileira.

É válido ressaltar que foi necessário realizar uma reformulação do tema, objetivo geral e específico da presente pesquisa aprovada pela Coordenação de Iniciação Científica do 
Centro Universitário de Brasília (UNICEUB), passando então a trazer um único estudo de caso, ao invés da análise de diversos crimes e acidentes ambientais ocorridos no país, o que inviabilizaria a sua conclusão no tempo cabível proposto no cronograma, o que em nada veio a prejudicar o tema e o título da pesquisa, ao contrário, permitiu maior precisão das afirmativas propostas em sua conclusão. 


\section{FUNDAMENTAÇÃO TEÓRICA}

A fundamentação teórica desta pesquisa buscou situar o problema do estudo frente as diversas obras existentes sobre ecocídio, passando pela sua criação e evolução histórica, chegando aos aspectos resultantes de sua inclusão como crime contra a humanidade pelo Tribunal Penal Internacional, "visto que o meio ambiente adquiriu um valor superior, considerando que sua proteção encontra seus fundamentos na segurança da humanidade presente e futura, e mais amplamente na segurança do planeta e do equilíbrio ecológico" (MARTIN-CHENUT, K., et. al., 2015) ${ }^{1}$.

Ao passar dos séculos, o conceito histórico e evolutivo de ecocídio, como um crime contra a humanidade nos direitos humanos e ambiental internacional, teve o ser humano como sujeito que encarou os recursos naturais como fontes inesgotáveis de energia e de capacidade de suporte contínuo aos ônus gerados pelo desenvolvimento desenfreado da modernização e do crescimento econômico.

A preservação ambiental, sinergicamente alinhada com o desenvolvimento econômico, era considerada utopia e radicalismo ambiental pelo sistema capitalista e de quem dele se nutria. Ou seja, todos sedentos pelo consumo compulsivo e lucro a qualquer custo, usurpando de inocentes (humanos ou não) o direito de um presente digno, equilibrado e sustentável em harmonia com os frutos deste legado à gerações futuras.

Foram necessárias diversas tragédias ambientais (naturais e antrópicas), alterações climáticas, aumento da fome, mortes de inocentes, proliferação de doenças, guerras, escassez de água, para que movimentos populares começassem a questionar tais comportamentos, principalmente a partir do pós-II Guerra Mundial. A ciência se incomodou, despertou, e por meio de suas descobertas, constatou o esgotamento dos recursos julgados infinitos.

A resistência capitalista enfraqueceu-se com os avanços tecnológicos e a conscientização humana deu seus primeiros passos pela preservação do meio ambiente, surgindo assim as primeiras discussões sobre o futuro do Planeta, especialmente, no âmbito

\footnotetext{
${ }^{1}$ MARTIN-CHENUT, Kathia; NEYRET, Laurent,; PERRUSO, Camila. Rumo à internacionalização da proteção penal do meio ambiente: dos ecocrimes ao ecocídio. Revista de Direito Internacional, Brasília, v. 12, n. 2, 2015 p. 540 569.
} 
internacional, ao ser constatado que era corrente em todos os povos.

O direito humano e o direito ambiental alinharam-se ao depositar ao direito penal internacional a universalidade imparcial da proteção do meio ambiente, iniciando-se por meio de Conferências e de diversas Declarações, até o surgimento dos primeiros Tratados, todos voltados à paz e a sobrevivência da Terra, o que inclui todos que nela habitam, seja raça humana ou não.

Ao passar dos séculos, o ser humano encarou os recursos naturais como fontes inesgotáveis de energia e de capacidade de suporte contínuo aos ônus gerados pelo desenvolvimento desenfreado da modernização e do crescimento econômico.

A preservação ambiental, sinergicamente alinhada com o desenvolvimento econômico, era considerada utopia e radicalismo ambiental pelo sistema capitalista e de quem dele se nutria. Ou seja, todos sedentos pelo consumo compulsivo e lucro a qualquer custo, usurpando de inocentes (humanos ou não) o direito de um presente digno, equilibrado e sustentável, em harmonia com os frutos deste legado à gerações futuras.

Foram necessárias diversas tragédias ambientais (naturais e antrópicas), alterações climáticas, aumento da fome, mortes de inocentes, proliferação de doenças, guerras, escassez de água, para que movimentos populares começassem a questionar tais comportamentos, principalmente após a II Guerra Mundial.

A ciência se incomodou, despertou, e por meio de suas descobertas, constatou o esgotamento dos recursos julgados infinitos. A resistência capitalista enfraqueceu-se com os avanços tecnológicos e a conscientização humana deu seus primeiros passos pela preservação do meio ambiente, surgindo assim as primeiras discussões sobre o futuro do Planeta, especialmente, no âmbito internacional, ao ser constatado o que era corrente em todos os povos.

O direito humano e o direito ambiental alinharam-se ao depositar no direito penal internacional a universalidade imparcial da proteção do meio ambiente, iniciando-se por meio de Conferências e de diversas Declarações, até o surgimento dos primeiros Tratados, todos voltados à paz e a sobrevivência da Terra, o que inclui todos que nela habitam, seja a raça humana ou não. 
Em face o exposto, compreender com brevidade a importância do direito internacional na proteção do meio ambiente, o surgimento do conceito de ecocídio, a responsabilidade do TPI como potencial guardião da proteção universal do meio ambiente ao julgar em último recurso os crimes contra a humanidade considerados de 4a velocidade pela Teoria das Velocidades do Direito Penal, com intuito de subsidiar o alicerce de referencial teórico desta pesquisa é o compromisso deste Capítulo que ora se inicia nas linhas a seguir diante do leitor, que é mais uma vez incitado a permanecer atento no aprofundamento desta pesquisa.

\section{Direito Internacional do Meio Ambiente: histórico, princípios e normas basilares}

Como um dos principais instrumentos de cooperação internacional, o Direito Internacional Ambiental se consolidou na área ambiental por estabelecer parâmetros mínimos de proteção ambiental ao promover a preservação do meio ambiente, o desenvolvimento sustentável, a qualidade de vida do mundo e a proteger a dignidade humana, ao contribuir para a viabilidade de sua existência na Terra, em consonância, com todos os Estados que se integram à ela².

A Ecologia ou qualquer outra ciência, não se confunde com o Direito Internacional Ambiental, pois de acordo com Guido Soares (2002), trata-se de um ramo do direito que: "regula aqueles aspectos relacionados ao meio ambiente que dependem, portanto, tãosomente da ação livre do homem (aqueles que implicam a escolha de valores conflitantes) e cuja regulamentação ultrapassa o interesse de um único Estado"3.

Para Paulo Henrique Portela (2015), seu objeto é o de contribuir com os avanços econômicos e tecnológicos que proporcionaram qualidade de vida à humanidade, sem eliminar as condições necessárias para manter essa mesma vida em condições de dignidade ao reparar os danos ambientais a ela causados, como prevenção de sua existência ${ }^{4}$. Ou seja, seria promover o desenvolvimento sustentável em harmonia com o desenvolvimento econômico, com a concretização dos direitos sociais e com o equilíbrio ambiental, preservando assim o meio ambiente.

\footnotetext{
2 PORTELA P. H. G. Direito Internacional Público e Privado - ed. 7. Salvador: JUSPODIVM, 2015, p. 437.

${ }^{3}$ SOARES, G. F. S. Direito Internacional Público. São Paulo: Atlas, 2002, p. 407.

${ }^{4}$ PORTELA P. H. G. Direito Internacional Público e Privado - ed. 7. Salvador: JUSPODIVM, 2015, p. 438.
} 
1.1. Histórico do Direito Internacional do Meio Ambiente

Segundo Paulo Henrique Portela (2015), historicamente, o Direito Internacional do Meio Ambiente possui marco inicial na Conferência das Nações Unidas sobre o Meio Ambiente Humano, conhecida como Conferência de Estocolmo, em 1972. Ao adotar medidas de escopo global referente aos avanços dos impactos negativos da atividade humana no meio ambiente, foi considerada a primeira reunião internacional sobre a preservação ambiental, uma vez que firmou a Declaração de Estocolmo sobre o Meio Ambiente Humano equiparadamente à Declaração Universal dos Direitos Humanos em matéria de proteção ambiental.

O enfoque motivador do encontro era o combate à poluição ambiental, uma vez que a impossibilidade de se desvincular as questões ambientais do desenvolvimento era materialmente evidente pelos inúmeros danos ambientais ocasionados pelo subdesenvolvimento e, em maior parte, pela poluição causada pelos países desenvolvidos ${ }^{5}$.

Com a evolução da temática e a piora das consequências da poluição ambiental no mundo, surgiu a necessidade de realizar um aperfeiçoamento da cooperação internacional ambiental estabelecida para que as preocupações ambientais passassem a compor como um dos principais tópicos nos debates internacionais atuais ${ }^{6}$.

Assim, tal necessidade foi consolidada pela Conferência das Nações Unidas para o Meio Ambiente e o Desenvolvimento - CNUMAD, conhecida também como Estocolmo + 20, Cúpula ou Cimeira da Terra, Rio 92 ou ECO 92, ocorrida no Rio de Janeiro, em 19927.

Como fruto de seus resultados, houve a aprovação da Declaração do Rio ou Carta do Rio e a Agenda 21, sendo essa última considerada o principal programa internacional de ação ambiental, e ainda, a celebração de dois importantes tratados: a Convenção-Quadro das Nações Unidas sobre Mudança de Clima e a Convenção sobre Diversidade Biológicå .

Houve ainda importantes proclamações segundo Valério de Oliveira Mazzuoli (2014), a saber: "a Declaração do Rio de Janeiro sobre Meio Ambiente e Desenvolvimento,

\footnotetext{
5 PORTELA P. H. G. Direito Internacional Público e Privado - ed. 7. Salvador: JUSPODIVM, 2015, p. 438.

${ }^{6}$ PACCIOLY, H.; SILVA, G. E. N. M.; CASELA, P. B. Manual de Direito Internacional Público - ed. 23. SAVAIVA, 2017, p. 321.

7 PORTELA P. H. G. Direito Internacional Público e Privado - ed. 7. Salvador: JUSPODIVM, 2015, p. 438

${ }^{8}$ MAZUOLI, V. O. Direito Internacional Público: parte geral - ed. 8.: RT, 2014, p. 184 - 185.
} 
atualizando a Declaração de Estocolmo; a proteção ambiental vinculada a necessidade do desenvolvimento sustentável; e por fim, a consolidação do direito a um meio ambiente equilibrado como direito humano"9.

\subsubsection{Princípios do Direito Internacional do Meio Ambiente}

Os princípios do Direito Internacional Ambiental não visam impedir o progresso econômico e tecnológico, há que se esclarecer que conforme Paulo Henrique Portela (2015) leciona: "os princípios fomentam, sim, o desenvolvimento sustentável". Ou seja, como o que ocorre em uma não degradação ambiental que possui como resultado uma piora nas condições de vida do ser humano.

São princípios do Direito Internacional Ambiental, de acordo com Paulo Henrique Portela $(2015)^{10}$ :

a) A impossibilidade de um Estado alterar as condições natural de seu território e causar danos a áreas fora de sua jurisdição, isto é, não pode um Estado causar "dano ambiental fronteiriço", afetando uma área pertencente ao domínio público internacional, como o alto mar, o espaço aéreo e o espaço extra-atmosférico;

b) A solidariedade, que preza pela inexistência de fronteiras para o dano ambiental;

c) A cooperação internacional, sendo de responsabilidade dos Estados cooperarem entre si sobre as matérias de meio ambiente;

d) A responsabilidade comum diferenciada, onde todos os Estados devem contribuir para a proteção e melhoria do meio ambiente do mundo, na proporção de suas responsabilidades da degradação ambiental e dispondo dos meios que possuem para combater as problemáticas ambientais;

e) O antropocentrismo, que considera a dignidade humana como centro das preocupações das normas ambientais ao promover a construção de um meio ambiente equilibrado em benefício das presentes e futuras gerações;

f) A promoção do desenvolvimento sustentável ao compatibilizar preservação e

\footnotetext{
${ }^{9}$ Idem, Ibidem, p. $184-185$.

${ }^{10}$ PORTELA P. H. G. Direito Internacional Público e Privado - ed. 7. Salvador: JUSPODIVM, 2015, p. 438.
} 
progresso, uma vez que a competência prioritária para tratar da preservação ambiental de um território é do Estado soberano o qual integra;

g) A competência prioritária dos Estados para formular e executar política ambiental dentro dos respectivos territórios, em conformidade com os parâmetros das normas internacionais estabelecidas, o que corresponde aos Estados não deixarem de observar as normas internacionais cabíveis para a preservação ambiental de seu território;

h) A informação, onde os Estados e os atores relevantes devem intercambiar o máximo de informações entre si sobre questões ambientais. Prevê, ainda, a disponibilização das informações deste intercâmbio ambiental amplamente divulgado para a sociedade; e

i) A precaução, o qual determina que ao haver uma ameaça de danos graves ou irreversíveis ao meio ambiente, a ausência de certeza científica absoluta, não deve ser utilizada como justificativa para o adiamento da tomada de decisão por parte dos Estados, da comunidade internacional e da sociedade como um todo. As medidas cabíveis para prevenir a degradação devem ser realizadas.

\subsubsection{Normas basilares do Direito Internacional do Meio Ambiente}

As normas basilares do Direito Internacional do Meio Ambiente, concisamente, são formadas por documentos ambientais internacionais, que apesar de não serem tratados, arrolam referenciais importantes para o meio ambiente no âmbito internacional, consideradas na prática por Paulo Henrique Portela como soft law ${ }^{11}$.

As normas basilares do Direito Internacional do Meio Ambiente que serão apontadas como fundamentação desta pesquisa, são as mesmas consideradas por Romeu Thomé (2016) como as principais fontes formais internacionais do direito ambiental, que reitera como exemplo dessa fonte formal, além das declarações a seguir, o estudo desenvolvido pelo Clube de Roma, publicado em 1972, titulado como "Limites do Crescimento", que concluiu que os seres humanos estavam (e continuam) esgotando os recursos dos quais depende a continuação da sua existência.

\footnotetext{
${ }^{11}$ THOMÉ R. F. da S. Manual de Direito Ambiental - ed. 6. Salvador: JUSPODIVM, 2016, p. 41.
} 


\subsubsection{Declaração de Estocolmo de 1972}

Com o intuito de estabelecer princípios comuns que possibilitasse orientar a humanidade no esforço de preservação e de melhoria do meio ambiente onde se vive, a Declaração de Estocolmo foi considerada o ponto de partida da construção do atual sistema internacional de proteção do meio ambiente, segundo Paulo Henrique Portela (2015) ${ }^{12}$.

Tais princípios constituíram-se no prolongamento da Declaração Universal dos Direitos do Homem, influenciando, a exemplo, a elaboração de um capítulo especial dedicado à proteção do meio ambiente na Constituição da República Federativa do Brasil de 1988, segundo José Afonso da Silva, conforme referencia Romeu Thomé (2016) ${ }^{13}$.

De acordo com a Declaração, o meio ambiente equilibrado é essencial para o bemestar dos seres humanos e o gozo dos seus direitos fundamentais, incluindo o direito à própria vida. No entanto, advertiu que, tendo em vista a rapidez da progressão ciência e tecnológica, o homem passou a deter o poder de transformar o meio ambiente de inúmeras maneiras e em escalas sem precedentes, e se feita de maneira equivocada, causaria danos maciços e irreversíveis ${ }^{14}$ não só para si como para todo o Planeta.

Paulo Henrique Portela (2015), trouxe à luz que a Declaração ainda considerou que proteção e a melhoria do meio ambiente são os aspectos mais importante para o bemestar dos povos e para o desenvolvimento do mundo inteiro, devendo ser de responsabilidade de todos os Estados e objetivo comum dos povos do mundo, assegurá-las para as gerações presentes e futuras, em harmonia com a paz e o desenvolvimento econômico e social.

Para o autor, essa responsabilidade deveria ser exercida pelos esforços comuns entre governos, prioritariamente, e sociedades no mundo inteiro, recorrendo a cooperação internacional e aos avanços da ciência que se adquiriu ao longo dos tempos, no que coubesse.

Considera o autor que a Declaração ainda estatuiu que o subdesenvolvimento é a causa da maioria dos problemas ambientais nos países em desenvolvimento e ações como o estabelecimento de metas foram determinadas com intuito de desenvolver esses povos,

\footnotetext{
12 PORTELA P. H. G. Direito Internacional Público e Privado - ed. 7. Salvador: JUSPODIVM, 2015, p. 440.

${ }^{13}$ THOMÉ R. F. da S. Manual de Direito Ambiental - ed. 6. Salvador: JUSPODIVM, 2016, p. 41.

${ }^{14}$ PORTELA P. H. G. Direito Internacional Público e Privado. Bahia: JUSPODIVM, 2015, p. 441.
} 
alinhando as diretrizes das metas, sempre, com as necessidades do meio ambiente.

Outras importantes determinações foram estabelecidas, afirma Paulo Henrique Portela (2015), como sobre os recursos naturais, que devem ser preservados, e quanto a capacidade da Terra de produzir seus recursos renováveis, devendo assim ser preservada, mantida, restaurada ou melhorada. Os recursos não renováveis, deveriam ser utilizados de forma a evitar seu esgotamento futuro, assegurando a toda a humanidade sua participação nos benéficos de seu uso, finaliza.

O combate contra a poluição foi determinado, e os agrupamentos humanos deveriam se desenvolver, buscando não apenas obter o máximo dos benefícios sociais e econômicos em comum, mas principalmente, primar por evitar repercussões prejudiciais ao meio ambiente ${ }^{15}$.

Foi aberta a possibilidade de transferência de recursos financeiros e tecnológicos por meio da cooperação internacional supracitada, devendo as políticas ambientais de todos os Estados estarem voltadas para a educação e para o desenvolvimento científico e tecnológico com fins no desenvolvimento para atender as necessidades do homem sem deixar de assegurar as do meio ambiente ${ }^{16}$.

A competência para administrar as políticas ambientais de cada Estado ficou a cargo das instituições nacionais, considerando sempre as obrigações internacionais. Os Estados mantiveram-se com seu direito soberano de explorar os recursos localizados em seus territórios ou em áreas sob sua jurisdição e controle, respeitando as políticas ambientais previamente estabelecidas e desde que tal exploração não viesse a prejudicar o meio ambiente de outros Estados ou de áreas sem nenhuma soberania, como o alto mar e o espaço aéreo internacional ${ }^{17}$.

Os compromissos acima referenciados, foram ratificados com a criação do Programa das Nações Unidas para o Meio Ambiente - PNUMA, constituído como uma agência do Sistema das Nações Unidas - ONU. O PNUMA foi o responsável por promover a

\footnotetext{
${ }^{15}$ Idem, Ibidem.

${ }^{16}$ THOMÉ R. F. da S. Manual de Direito Ambiental - ed. 6. Salvador: JUSPODIVM, 2016, p. 41.

17 PORTELA P. H. G. Direito Internacional Público e Privado - ed. 7. Salvador: JUSPODIVM, 2015, p. 441.
} 
conservação do meio ambiente e o uso eficiente de recursos no contexto do desenvolvimento sustentável ${ }^{18}$

É válido ressaltar que até a Declaração do Rio de 1992, outros importantes encontros internacionais ocorreram com o objetivo de se discutir as questões ambientais, como a Convenção de Basiléia sobre o Controle de Movimentos Transfronteiriços de Resíduos Perigosos e seu Depósito em 1979. Importantes série de seminários sobre estilos alternativos de desenvolvimento promovidos pelo PNUMA em colaboração com as Comissões Econômicas Regionais das Nações Unidas, que teve seus debates refletidos no Relatório Brundtland em 1987, denominado de "Nosso futuro comum", conduzindo à convocação da Conferência do Rio de Janeiro em $1992^{19}$.

Nas palavras de Romeu Thomé (2016): "o reflexo das discussões ocorridas na Suécia, estimulou a criação de órgãos ambientais em diversos países, inclusive no Brasil, que criou e instituiu a Secretaria Especial do Meio Ambiente - SEMA, por meio do Decreto no 73.030/73. Debates relacionados à proteção ambiental fortaleceram os movimentos organizados pela sociedade civil e a atuação das organizações não-governamentais de defesa do meio ambiente".

\subsubsection{Declaração do Rio de 1992}

Com o objetivo principal de estabelecer uma aliança mundial com a criação de novos níveis de cooperação internacional entre os Estados e setores-chaves da sociedade ${ }^{20}$, a Declaração do Rio sobre o Meio Ambiente e Desenvolvimento ou Carta do Rio proclamada pela ECO 92, manteve então todos os valores consagrados na Declaração de Estocolmo, mas os atualiza à luz dos avanços ocorridos em vinte anos de negociações internacionais no campo ambiental, dos progressos científicos e das mudanças ocorridas no meio ambiente do Planeta ${ }^{21}$.

Paulo Henrique Portela (2015) afirma que no início da Declaração, salientou-se de imediato que "os seres humanos estão no centro das preocupações com o desenvolvimento

\footnotetext{
${ }^{18}$ THOMÉ R. F. da S. Manual de Direito Ambiental - ed. 6. Salvador: JUSPODIVM, 2016, p. 42.

${ }^{19}$ Idem, Ibidem.

20 THOMÉ R. F. da S. Manual de Direito Ambiental - ed. 6. Salvador: JUSPODIVM, 2016, p. 43.

${ }^{21}$ PORTELA P. H. G. Direito Internacional Público e Privado - ed. 7. Salvador: JUSPODIVM, 2015, p. 441.
} 
sustentável, tendo direito a uma vida saudável e produtiva, desde que em harmonia com o ambiente onde vive". A partir de então o Direito Internacional Ambiental foi considerado como antropocêntrico, consagrando a expressão "desenvolvimento sustentável"22 e o Princípio da precaução 23 .

Ainda pelo autor, as principais determinações da Declaração concernem em que:

a) Para se alcançar um desenvolvimento sustentável e uma qualidade de vida mais elevada para todos, há de se combinar a erradicação da pobreza e a noção de que a proteção ambiental é parte integrante do processo de desenvolvimento. Assim, cabendo aos Estados reduzir e eliminar os padrões insustentáveis de produção e consumo, e ainda, promover políticas demográficas adequadas;

b) Ao se edificar o desenvolvimento sustentável, os Estados precisam ter responsabilidades comuns, mesmo que diferenciadas. Neste sentido, os países desenvolvidos reconheceram que a busca internacional pelo desenvolvimento sustentável lhes cabe em maior parte, pela pressão que sofrem por seus povos e por deterem grande parte dos recursos financeiros e tecnológicos do mundo. Assim, em prol de se atender a necessidade de todos, há que se priorizar os Estados ainda em desenvolvimento;

c) A ampliação mais alta possível na participação de todos os agentes sociais, sendo essa a melhor maneira de trata as questões ambientais. Para isso, as autoridades públicas devem possibilitar o maior acesso cabível às informações relativas ao meio ambiente, principalmente a cerca de materiais e atividades perigosas em suas comunidades, dando oportunidade de participação no processo decisório e aos mecanismos de defesa administrativos e judiciais existentes ao seu povo;

d) A legislação ambiental nacional deve refletir a realidade para a qual foi criada, uma vez que seriam adequadas para uns e inadequadas para outros, em especial os países em desenvolvimento;

22 THOMÉ R. F. da S. Manual de Direito Ambiental - ed. 6. Salvador: JUSPODIVM, 2016, p. 43.

23 PORTELA P. H. G. Direito Internacional Público e Privado - ed. 7. Salvador: JUSPODIVM, 2015, p. 441. 
e) As medidas internacionais sobre problemáticas ambientais transfronteiriças ou globais, com base na cooperação internacional, devem fundamentar-se no consenso entre os entes estatais envolvidos, e ainda, os Estados devem efetivamente cooperar para a desestimulação ou prevenção da realocação e transferência de atividades e substâncias que causem degradação ambiental grave ou que sejam prejudiciais à saúde humana, para outros Estados;

f) Ao tratamento internacional do tema dos desastres naturais, um Estado que venha a sofrer desastres naturais ou outras situações de emergência que possa vir a provocar súbitos efeitos prejudiciais ao meio ambiente, deve notificar os Estados que possam também vir a ser afetados. Nos casos de catástrofes, todos os esforços possíveis devem ser enviados pela comunidade internacional para apoiar o Estado prejudicado, apoiando assim seu povo, sua nação; e finalmente,

g) A necessidade de paz no mundo, uma vez que a guerra é danosa ao meio ambiente e este precisa de uma proteção que é interdependente e indivisível, assim como a paz. Neste sentido, estando de acordo com o fulcro no artigo 8ํ, §2으, "b", "iv", do Estatuto de Roma.

É válido ressaltar que documentos importantes também foram elaborados ao final do encontro segundo Romeu Thomé (2016), como a Convenção sobre Mudanças do Clima (que originou o Protocolo de Kyoto, cinco anos mais tarde), Convenção sobre Diversidade Biológica (objeto da conservação da biodiversidade, o uso sustentável de seus componentes e a divisão equitativa e justa dos benefícios gerados com a utilização de recursos genéticos), e a Declaração de Princípios sobre o uso das Florestas, sendo todos com temas e ações bem específicas ${ }^{24}$.

Há que reiterar que tanto esta Declaração como a Agenda 21 são frutos da $E C O$ 92, sendo aprovadas ao final deste evento.

\subsubsection{Agenda 21}

Considerada um programa de plano de ação que, segundo Romeu Thomé (2016):

\footnotetext{
${ }^{24}$ THOMÉ R. F. da S. Manual de Direito Ambiental - ed. 6. Salvador: JUSPODIVM, 2016, p. 45.
} 
"viabiliza um novo padrão de desenvolvimento ambiental racional, isto é, um programa que concilia métodos de proteção ambiental, justiça social e eficácia econômica"25, não pode ser considerada um tratado, convenção ou declaração internacional, mas sim uma importante norma para as políticas ambientais dos Estados e das instituições em geral. Como consequência, isso permitiu sua classificação como soft low ${ }^{26}$, uma vez que sua carência de imperatividade e de mecanismos de sanção aos países que desrespeitarem o documento, não o desmerecem, ao contrário, o qualificam ${ }^{27}$.

A Agenda 21 é extensa em seus quarenta capítulos que subdividem em quatro seções. Guido Soares (2005) a considera um "documento normativo reduzido"28, que nesta pesquisa será apresentada com brevidade, limitando-se na essência de cada seção, pois para Paulo Henrique Portela (2015) já revela nos títulos dos seus capítulos a sua preocupação com a proteção internacional do meio ambiente de maneira ampla ${ }^{29}$.

Segundo Romeu Thomé (2016), a Agenda 21 é mais que um "código de boas intenções", é um plano de ação para ser adotado global, nacional e localmente, por organizações do sistema das Nações Unidas, governo e pela sociedade civil, em todas as áreas em que a ação humana impacta o meio ambiente ${ }^{30}$.

Para o Supremo Tribunal Federal, destaca o autor:

"(...) a questão do meio ambiente, hoje, especialmente em função da Declaração de Estocolmo sobre o Meio Ambiente (1972) e das conclusões das Conferências das Nações Unidas sobre Meio Ambiente e Desenvolvimento (Rio/92), passou a compor um dos tópicos mais expressivos da nova agenda internacional (GERALDO EULÁLIO DO NASCIMENTO E SILVA, "Direito Ambiental Internacional", $2 a$ ed., 2002, Thex Editora), particularmente no ponto em que se reconheceu, ao gênero humano, o direito fundamental à liberdade, à igualdade e ao gozo de condições de vida adequada, em ambiente que Ihe permita desenvolver todas as suas potencialidades em clima de dignidade e de bem-estar" (STF, ADI 3540 MC-DF, Rel. Min. Celso de

\footnotetext{
${ }^{25}$ THOMÉ R. F. da S. Manual de Direito Ambiental - ed. 6. Salvador: JUSPODIVM, 2016, p. 45.

${ }^{26}$ PORTELA P. H. G. Direito Internacional Público e Privado - ed. 7. Salvador: JUSPODIVM, 2015, p. 441.

${ }^{27}$ MILARÉ E. Direito do Ambiente - ed. 5. São Paulo: Revista dos Tribunais, 2007, p.89.

${ }^{28}$ SOARES, G. F. S. A proteção internacional do meio ambiente. Série entender o mundo - vol. 2. São Paulo: Manole, 2005, p. 67.

${ }^{29}$ PORTELA P. H. G. Direito Internacional Público e Privado - ed. 7. Salvador: JUSPODIVM, 2015, p. 443.

${ }^{30}$ THOMÉ R. F. da S. Manual de Direito Ambiental - ed. 6. Salvador: JUSPODIVM, 2016, p. 45.
} 
Mello, DJ 03/02/2016, p. 00014).

A Agenda 21 e os compromissos da carta de princípios do Rio foram fortemente reafirmadas durante a Cúpula de Joanesburgo, ou Rio +10 , em 2002, sendo considerada esta última como fonte normativa do Direito Ambiental, mas não do Direito Internacional Ambiental ${ }^{31}$

\subsection{Danos Ambientais e Ecológicos: responsabilidade e reparação internacional}

A responsabilidade internacional ambiental e ecológica é objetiva ou por risco. Quer dizer, não se investiga sobre a eventual culpa do agente pelo dano, e sim, bastando a configuração dos prejuízos, para que surja a obrigação de reparação, independente da forma em que o agente do dano tenha concorrido ou não para o feito, sendo irrelevante se a atividade é ou não considerada "perigosa" ou proibida pelo Direito Internacional ${ }^{32}$.

Paulo Henrique Portela (2015) ensina que os tratados que preveem à proteção do meio ambiente quanto à responsabilidade internacional por danos ambientais e ecológicos e que se encontram em vigor para o Brasil, são os seguintes: Convenção de Viena sobre Responsabilidade Civil por Danos Nucleares, de 1953 (Decreto no 991/93); Convenção Internacional sobre Responsabilidade Civil em Danos Causados por Poluição por Óleo, de 1969 (Decreto no 79.437/77), amparada pela Organização Marítima Internacional - OMI; e a Convenção Internacional sobre Responsabilidade Internacional por Danos Causados por Objetos Espaciais, de 1972 (Decreto no 71.981/73).

\subsection{Direitos Humanos e o Meio Ambiente}

A matéria ambiental tem íntima relação com a proteção dos direitos humanos, uma vez que Paulo Henrique Portela (2015) afirma que: "a degradação ambiental afeta diretamente qualidade de vida humana e pode, em última instância, extinguí-la, ao passo que a proteção ambiental e o desenvolvimento sustentável esta relacionado, diretamente, com a promoção da dignidade humana"33, o que alimenta cada dia mais o direito ao meio ambiente

\footnotetext{
${ }^{31}$ THOMÉ R. F. da S. Manual de Direito Ambiental - ed. 6. Salvador: JUSPODIVM, 2016, p. 43.

32 PORTELA P. H. G. Direito Internacional Público e Privado - ed. 7. Salvador: JUSPODIVM, 2015, p. 445.

33 PORTELA P. H. G. Direito Internacional Público e Privado - ed. 7. Salvador: JUSPODIVM, 2015, p. 452.
} 
equilibrado ser considerado rol dos direitos humanos.

É preciso pensar. Como o tema ambiental só ganhou efetividade em 1972, com a Conferência de Estocolmo, e os pacto de direitos humanos, a saber: Pacto dos Direitos Civis e Pacto dos Direitos Econômicos, Sociais e Culturais, que foram assinados em 1966, e a Convenção Americana de Direitos Humanos - CADH ou Pacto de San José da Costa Rica de 1969, não há como mencionar o tema ambiental ao que já estava firmado, tanto no Sistema Global como no Regional.

Doravante, tal ausência não furta a importância do meio ambiente para a proteção e promoção da dignidade da pessoa humana, nem a extingue do rol dos direitos da pessoa humana, salienta Paulo Henrique Portela (2015), uma vez que o primeiro princípio da Declaração de Estocolmo, ressalva "ao gênero humano, o direito fundamental à liberdade, à igualdade e ao gozo de condições de vida adequada, em ambiente que Ihe permita desenvolver todas as suas potencialidades em clima de dignidade e de bem-estar ${ }^{\prime 134}$.

O décimo princípio da Declaração do Rio também destaca o direito a participação e o acesso a informação sobre as questões ambientais pelo homem, que é reiterado em tratados como a Convenção das Nações Unidas sobre Mudança do Clima, o Protocolo de Cartagena e a Convenção sobre a Diversidade Biológica, de 1992 (ao reconhecer o direito das presentes e das futuras gerações à preservação da biosfera) ${ }^{35}$.

Os tratados de direitos humanos posteriores à Declaração de Estocolmo de 1972, reconheceram expressamente tal relação, como a Convenção sobre Direitos da Criança, de 1989, que declarou como direito à saúde das crianças, o fortalecimento dos alimentos serem nutridos em água potável, "tendo em vista os perigos e riscos da proteção ambiental" (artigo $24, \S 10$ e 2 의 36 .

Valério de Oliveira Mazzuoli (2014), destaca que a Organização dos Estados Americanos - OEA reconheceu, em 04/04/2002, a relação entre os direitos humanos e o meio ambiente ao ressaltar no Relatório "Direitos Humanos e Meio Ambiente" que a Conferência

\footnotetext{
${ }^{34}$ MAZZUOLI, V. O. Direito Internacional Público: parte geral - ed. 8.: São Paulo: RT, 2014, p. 172.

35 PORTELA P. H. G. Direito Internacional Público e Privado - ed. 7. Salvador: JUSPODIVM, 2015, p. 452.

${ }^{36}$ Idem, Ibidem, p. 453.
} 
das Nações Unidas sobre o Meio Ambiente Humano de 1972, "declarou que o meio ambiente humano, o natural e o artificial são essenciais para o bem-estar do homem e para o gozo dos direitos humanos"137.

Outro vínculo entre os direitos humanos e o meio ambiente está no artigo 11, §1으 do Protocolo de San Salvador, protocolo este adicional à Convenção Americana de Direitos Humanos em matéria de Direitos Econômicos, Sociais e Culturais ao prever que "toda pessoa tem direito a viver em ambiente sadio"38, promulgado no Brasil pelo Decreto no 3.321/99.

\subsection{O ecocídio como crime contra a humanidade: conceito, breve histórico e expectativas (atuais e futuras)}

De acordo com o levantamento bibliográfico e doutrinário apresentado nesta pesquisa, há a existência de muitos acordos internacionais em forma de códigos de conduta, resoluções das Nações Unidas, Tratados, Convenções, Protocolos, dentre outros. No entanto, nenhum trata "o dano e a destruição em massa ambiental", sendo estes apresentados em tais documentos apenas em forma escalonada, isto é, não existindo hoje no mundo nenhum acordo internacional que proíba ecocídio e nem o constitua como crime internacional expressamente.

A proposta de se discutir internacionalmente sobre o ecocídio é que se crie um dever legal de cuidado que mantenha as ações de pessoas de "responsabilidades superiores", como tomadores de decisão civis ou jurídicos, particular ou públicos (o que inclui governantes) à conta em um Tribunal Exceção, como o TPI.

Ao configurar o regimento do TPI, o Estatuto de Roma é um dos documentos legais mais poderosos do mundo, atribuindo aos crimes mais graves - conhecidos também como "crimes contra a humanidade ou contra a paz" (a saber: os crimes de genocídio, contra a humanidade, de guerra e de agressão) - uma preocupação sólida da comunidade internacional, para além de todas as outras leis já existentes.

\footnotetext{
${ }^{37}$ MAZZUOLI, V. O. Direito Internacional Público: parte geral - ed. 8.: São Paulo: RT, 2014, p. 174.

38 PORTELA P. H. G. Direito Internacional Público e Privado - ed. 7. Salvador: JUSPODIVM, 2015, p. 453.
} 
Diante deste contexto, é válido discorrer ainda sobre o que ensejou o surgimento do ecocídio no mundo como crime, apresentando ao leitor o seu conceito, breve histórico evolutivo, expectativas atuais e futuras de organismos que disseminam a sua importância e fomentam a sua previsão não só no Estatuto de Roma, mas incitam o uso e a proliferação de seu conceito em artigos científicos, debates jurídicos e no dia-a-dia da sociedade.

\subsubsection{Conceito de ecocídio}

O conceito de Ecocídio é definido por Polly Higgins (2010) como: "perda ou dano ou destruição extensiva de um ou vários ecossistemas num determinado território, seja por ação humana ou por outras causas, de tal forma que o gozo pacífico pelos seus habitantes foi ou será severamente diminuída"39.

É também conceituado pela Organização Eradicatin Ecologe (2018), como: "dano e destruição em massa ambiental de ecossistema(s) de um determinado território, seja por ação humana ou por outras causas, que tenham afetado o gozo pacífico pelos habitantes da localidade, sendo seu usufruto severamente diminuído pelo gozo pacífico dos habitantes de um outro território que tenha seu usufruto severamente diminuído"40.

\subsubsection{Breve histórico evolutivo do ecocídio no mundo}

A Conferência de Organização Internacional das Nações Unidas, em 1945, ao promulgar a "Carta das Nações Unidas" - documento este promulgado pelo governo brasileiro por meio do Decreto no 19.841/45 -, determina em seu artigo 13 que a Assembléia Geral iniciaria estudos e faria recomendações destinada ao incentivo do desenvolvimento progressivo do direito internacional, bem como a sua codificação ${ }^{41}$.

Eradicatin Ecologe (2018) considera como resultado dessa determinação, à Assembléia Geral em 1947, que instituiu a Comissão de Direito Internacional - com a aprovação de seu Estatuto -, uma vez que determinou a preparação de um Projeto de Código

\footnotetext{
39 HIGGINS, P. Eradicating Ecocide: Law and Governance to Stop the Destruction of the Planet. ShepheardWalwyn: Londres, 2010.

${ }^{40}$ ERADICATING ECOCIDE. Disponível em: http://eradicatingecocide.com. Acesso em 13 nov. 2017.

${ }^{41}$ Idem, ibidem.
} 
de Crimes contra a Paz e Segurança da Humanidade, conhecido como Estatuto de Roma de 1998, bem como um projeto de declaração sobre os direitos e deveres dos Estados.

Ainda pela organização supracitada, em 1948, a Comissão de Direito Internacional é estabelecida pela Assembléia Geral das Nações Unidas para a "promoção do desenvolvimento progressivo do direito internacional e a sua codificação". No entanto, somente a partir de 1970, é que há um apoio crescente entre o governo, as Nações Unidas e as comunidades para a inclusão do ecocídio como o quinto crime internacional, estando ao lado do crime de genocídio, a partir de uma alteração do Estatuto de Roma. Desta maneira, o ecocídio passou a ser reconhecido como parte de um conjunto emergente de "Direito da Terra ou de Jurisprudência da Terra".

Em 1978, ainda pela Eradicatin Ecologe (2018), iniciaram as discussões do Projeto do Código de Crimes Contra a Paz e Segurança, tendo as responsabilidades do Estado como foco de discussão. Já em 1998, o Projeto do Código de Crimes Contra a Paz e Segurança da Humanidade é renomeado com o Estatuto de Roma, que entrou em vigor em 2002, no entanto, considerando apenas quatro crimes internacionais e excluindo o ecocídio do texto base por pressão de países como EUA, Reino Unido e Holanda.

\subsubsection{Breve histórico evolutivo do ecocídio como uma responsabilidade do Estado}

O conceito de ecocídio como uma responsabilidade do Estado possui como marco histórico o século XX, iniciando sua primeira referência internacional como crime de Estado na década de 1970, durante a Conferência sobre Guerra e Responsabilidade Nacional, em Washington, quando Arthur Galston propôs um novo acordo internacional para proibi-lo ${ }^{42}$. Galston (biólogo norte-americano) identificou os efeitos do desfolhante de uma substância química que mais tarde evoluiu para o "agente laranja", sendo assim, o primeiro a citar o ecocídio como um grande dano e de destruição de ecossistemas em larga escala ${ }^{43}$ ao definilo como: "(...) devastação e destruição que visa danificar ou destruir a ecologia de áreas geográficas em detrimento de toda a vida, seja humana, animal ou vegetal".

\footnotetext{
42 MEGRET, F. O caso para um crime Geral Internacional Contra o Meio Ambiente. SSRN's: 2010.

${ }^{43}$ ERADICATING ECOCIDE. Disponível em: http://eradicatingecocide.com. Acesso em 27 nov. 2017.
} 
Ainda em 1970, a ideia de expandir a Convenção do Genocídio de 1948, levou a extensa investigação para saber se o ecocídio deveria ser incluído como um crime internacional pelas Nações Unidas. A Subcomissão para a Prevenção da Discriminação e Proteção das Minorias preparou um estudo para discutir a eficácia da Convenção do Genocídio, conhecido como "Relatório Ruhashyankiko", que propôs considerar o ecocídio, bem como o genocídio cultural na lista de crimes internacionais. Nos anos seguintes, o ecocídio como crime foi examinado por diversos grupos de trabalho e mencionado em vários estudos, embora não tão abrangentes ${ }^{44}$.

Em 1972, na Conferência das Nações Unidas de Estocolmo sobre o Ambiente Humano, Olof Palme (primeiro-ministro da Suécia), em seu discurso de abertura, equiparou explicitamente a guerra do Vietnã como um ecocídio ao ter usado o "agente laranja" como arma de extermínio, caracterizado por ele como "ultraje por vezes descrito como ecocídio". O Vietnã posteriormente, introduziu o ecocídio como crime doméstico em $1990^{45}$.

Outros, incluindo Indira Gandhi (da Índia) e Tang Ke, o líder da delegação chinesa na Conferência, também denunciaram a guerra em termos humanos e ambientais, afirmarem o ecocídio como um crime internacional. Um Grupo de Trabalho sobre Crimes Contra o Meio Ambiente foi formado na conferência, e um projeto de Convenção do Ecocídio foi apresentado nas Nações Unidas em $1973^{46}$.

Em 1972, a Organização Fellowship of Reconciliation (uma sociedade internacional de reconciliação), ao reunir um grupo de trabalho intitulado "Dai Dong Environment", patrocinou uma Convenção sobre a Guerra Ecocida em Estocolmo, Suécia. Diversos especialista participaram, incluindo Richard Falk, especialista em direito internacional dos crimes, que definiu e condenou o ecocídio como um crime de guerra internacional. Em 1973, Richard Falk (1973), elaborou uma Convenção do Ecocídio afirmando explicitamente em sua abertura "que o homem consciente e inconscientemente inflige danos irreparáveis ao meio ambiente em tempos de guerra e paz"147.

\footnotetext{
${ }^{44}$ Idem, Ibidem.

${ }^{45}$ ERADICATING ECOCIDE. Disponível em: http://eradicatingecocide.com. Acesso em 27 nov. 2017.

${ }^{46}$ Idem, Ibidem.

47 FALK, R. A. Guerra Ambiental e Ecocídio - Factos, avaliação e propostas, vol. 1 - Deepdyve: Boletim de propostas de paz, 1973.
} 
Em 1978, o projeto dos artigos que deu fruto ao Estatuto de Roma, com relação a Responsabilidade do Estado e a criminalidade internacional incluiu: "um crime internacional (que) poderia resultar, nomeadamente, de: "uma violação grave de uma obrigação internacional de importância essencial para a salvaguarda e preservação do meio ambiente humano, tais como a proibição da poluição maciça da atmosfera ou dos mares", sendo-lhe favorável a sua inclusão como crime na Roménia, Santa Sé, Áustria, Polônia, Ruanda, Congo e Omã ${ }^{48}$.

Em 1985 o relatório "Whitaker", elaborado por Benjamin Whitaker (19845), foi encomendado pela Subcomissão de Promoção e Proteção dos Direitos Humanos com intuito de analisar questões sobre prevenção e repressão do crime de genocídio, no entanto, alguns membros da comissão propuseram que a definição de genocídio fosse ampliada, incluindo o genocídio cultural ou "etnocídio", e também "ecocídio", ao considerarem como: "alterações adversas, muitas vezes irreparáveis, ao meio ambiente que ameaçam a existência de populações inteiras, deliberadamente ou com negligência criminosa"49.

Desse modo, o projeto de resolução preparado para a Comissão de Direitos Humanos, como parte da revisão, incluiu a recomendação de Whitaker e permitiu a expansão e o aprofundamento do estudo das noções de genocídio, etnocídio e ecocídio. Na 38a Sessão do relatório da ONU, a Subcomissão trilhou o caminho que eles estavam a percorrer na história do direito internacional ${ }^{50}$.

Em 1987 as discussões de crimes internacionais continuaram na Comissão de Direito Internacional, e foi proposto então que a lista de crimes internacionais incluíssem o ecocídio, "como um reflexo da necessidade de proteger e preservar o meio ambiente, bem como o primeiro uso de armas nucleares, o colonialismo, apartheid, agressão econômica e mercenarismo" 51 .

Em 1991 o projeto do Código de Crimes Contra a Paz e Segurança da Humanidade continha 12 crimes, sendo o ecocídio substituído por "danos intencionais e graves ao meio

\footnotetext{
${ }^{48}$ ERADICATING ECOCIDE. Disponível em: http://eradicatingecocide.com. Acesso em 30 nov. 2017.

${ }^{49}$ WHITAKER, B. Revised and updated report on the question of the prevention and punishment of the crime of genocide. Thirty-eighth session, Item 4 of the provisional agenda, ECN. 4, Sub.2, 1985.

${ }^{50}$ Idem, Ibidem.

51 UNITED NATIONS PUBLICATION. Yarbook of the International Law Commission. v. 1, 1987.
} 
ambiente" (artigo 26). O projeto dos artigos foram transmitidos aos governos de Estado para seus comentários e observações ${ }^{52}$.

Em 1993, o Secretário-Geral da Comissão de Direitos Humanos recebeu 23 respostas dos Estados-Membros e uma resposta de um Estado não membro. Em síntese, foram: Austrália, Áustria, Belarus, Bélgica, Brasil, Bulgária, Costa Rica, Equador, Grécia, Holanda, os países nórdicos (Dinamarca, Finlândia, Islândia, Noruega, Suécia), Paraguai, Polônia, Senegal, Sudão, Turquia, Reino Unido, EUA, Uruguai e Suíça. Destes, apenas três países: Holanda, Reino Unido e Estados Unidos da América, se opuseram à inclusão de um crime ambiental. A Holanda suportou quatro crimes (excluindo o ecocídio). EUA e Reino Unido se opuseram à proposta de Código per si, isto é, os EUA citou "imprecisão" e o Reino Unido considerou os crimes contra o meio ambiente como sendo um "crime internacional desconhecido e um passo longe demais" ${ }^{153}$.

Entre os anos de 1995 e 1996, a Comissão de Direitos Humanos reduziu os 12 crimes em 6. O projeto de discussões do código mudou-se para a Sexta Comissão da Assembléia Geral, que em encontro realizado em 1995, apresentou um relatório especial favorável em manter o artigo que tratava sobre os "crimes intencionais de graves danos ao meio ambiente". O que motivou o levantamento de preocupações no que concerniam ao fato de que o dano ambiental é uma responsabilidade do Estado, sendo assim removido, com também ocorreu com o crime ambiental durante o tempo de paz ${ }^{54}$.

Eradicating Ecocide (2017) esclarece que em 1996, o advogado australiano Mark Gray publicou sua proposta de 1988, sobre a criminalização internacional de ecocídio baseando-se no direito internacional estabelecido em direitos ambientais e humanos. Ele demonstrou que Estados, e possivelmente, indivíduos e organizações, ao fazer ou permitir a realização de danos ao ambiente natural como uma violação maciça, ao invés de exercerem o dever de cuidado para o bem da humanidade em geral, devem ser punidos pela imprudência ou negligência a serem identificadas como ecocídio, pois provocaram graves, extenso e duradouro danos ecológicos de impactos internacionais.

\footnotetext{
52 ERADICATING ECOCIDE. Disponível em: http://eradicatingecocide.com. Acesso em 30 nov. 2017.

53 UNITED NATIONS PUBLICATION. Yarbook of the International Law Commission. v. 2, primeira parte, 1993.

${ }^{54}$ ERADICATING ECOCIDE. Disponível em: http://eradicatingecocide.com. Acesso em 30 nov. 2017.
} 
A organização supracitada elucida que com relação a manifestação no Comitê Jurídico, 19 países se manifestaram a favor da manutenção do crime de "danos ao meio ambiente" na lista dos crimes previstos no projeto do Estatuto de Roma, e apenas três se manifestaram contra, incluindo o Brasil. Em 05/07/1996, o Projeto de Código final de Crimes Contra a Paz e Segurança da Humanidade foi aprovada em segunda leitura pelo Comitê. O ecocídio não foi reintegrado e o "dano intencional e grave ao ambiente" foi removido, como o foi na seção sobre Responsabilidade do Estado.

Em 1998, o projeto do Código foi finalmente renomeado como: Estatuto de Roma. O ecocídio foi excluído e qualquer menção de dano ambiental foi restrito a apenas "guerracrime", e não a um "paz-crime". Nos termos da Convenção Ambiental de Modificação de 1977, os danos ambientais em tempo de guerra, que expressava a destruição ambiental como um dano ambiental "generalizado, ou a longo prazo ou graves ao ambiente natural", passou a ser escrito como "danos generalizados, a longo prazo e graves ao ambiente natural"55.

Tomuschat (1996) critica que o Estatuto de Roma, após o longo retrocesso do ecocídio em seu teor, considerou o dano ambiental como um crime apenas em circunstâncias limitadas, ou seja, em tempos de guerra quando "um ataque intencional causar a perda de vidas humanas ou provocar danos a civis ou ao meio ambiente é que devem ser caracterizados como " danos generalizados, a longo prazo e graves ao ambiente natural", o que torna praticamente impossível processar alguém por este crime, devido a dificuldade de sua comprovação.

Diante de toda a frustração gerada com a aprovação do Estatuto de Roma sem a previsão do crime de ecocídio, há um alento de que nem tudo foi perdido das infinitas discussões sobre a matéria, pois alguns países inseriram em seus ordenamentos jurídicos a previsão e tipificação do ecocídio como crime, assim ${ }^{56}$ :

a) Código Penal Vietnã de 1990, artigo 278: "destruição do ambiente natural, seja cometido em tempo de paz ou de guerra, constitui um crime contra a humanidade";

\footnotetext{
55 TOMUSCHAT, C. YEARBOOK. v. 2, 1996, p. 24.

${ }^{56}$ ERADICATING ECOCIDE. Disponível em: http://eradicatingecocide.com. Acesso em 30 nov. 2017.
} 
b) Código Penal da Federação Russa, 1996, artigo 358: “a destruição maciça da fauna e flora, a contaminação dos recursos atmosfera ou da água, bem como outros atos capazes de causar uma catástrofe ecológica, constitui um crime contra a paz e a segurança da humanidade";

c) Código Penal Cazaquistão de 1997, artigo 161: "destruição em massa da fauna ou flora, poluição da atmosfera, dos recursos agrícolas ou da água, bem como outros atos que tenham causado ou são capazes de causar uma catástrofe ecológica, constitui um crime contra a paz e a segurança da humanidade";

d) Código Penal Quirguistão de 1997, artigo 374: "destruição em massa da flora e fauna, envenenamento dos recursos atmosfera ou da água, bem como outros atos capazes de causar uma catástrofe ecológica, seja passível de privação de liberdade";

e) Código Penal Tadjiquistão de 1998, artigo 400: “extermínio em massa de flora ou fauna, envenenando dos recursos atmosfera ou da água, bem como outros atos capazes de causar uma catástrofe ecológica, constitui um crime contra a paz e a segurança da humanidade";

f) Código Penal Geórgia de 1999, artigo 409: "contaminação da atmosfera, da terra e dos recursos hídricos, a destruição em massa de flora e fauna ou qualquer outra ação que poderia ter causado um desastre ecológico - é punível com pena de prisão que se estende de oito a vinte anos de comprimento";

g) Código Penal Belarus de 1999, artigo 131: "destruição maciça da fauna e flora, a poluição dos recursos atmosfera e de água, bem como qualquer outro ato susceptível de causar um desastre ecológico";

h) Código Penal Ucrânia de 2001, artigo 441: "destruição em massa de flora e fauna, envenenamento de recursos de ar ou de água, e também quaisquer outras ações que podem causar um desastre ambiental. É punível com prisão por um período de oito a quinze anos";

i) Código Penal da República de Moldova, 2002, artigo 374: “a destruição deliberada e massiva da fauna e flora, a poluição da atmosfera ou 
envenenamento de recursos de água, bem como outros atos capazes de causar uma catástrofe ecológica, seja passível de privação de liberdade"; e

j) Código Penal da República da Arménia de 2003, artigo 394: “destruição em massa de flora ou fauna, envenenando o ambiente, os solos ou recursos hídricos, bem como a implementação de outras ações causando uma catástrofe ecológica. É punido com pena de prisão pelo prazo de dez a quinze anos".

Para a Organização Eradicating Ecocide (2017), a inserção do crime de ecocídio no ordenamento jurídico dos países supracitados, demonstra além de uma força propulsora na década de 90, como também no século XXI. Isso ocorre, uma vez que os países que o incluíram como crime, permitem uma clara e evidente resposta de que o reconhecem sim como crime, independente da globalização do direito e das relações internacionais, demonstrando respeito e preocupação com tal matéria tão próxima a atualidade como do futuro que se espera.

De acordo com levantamentos ainda da organização, em 2010, advogada escocesa Polly Higgs, titulada como "advogada da Terra" por ser autora e especialista em liderança sobre o ecocídio, apresentou à Comissão de Direito da ONU sua proposta para incluir o ecocídio no Estatuto de Roma, como quinto crime contra a paz. Após sua proposta, a luta do ecocídio como crime internacional viralizou, sendo considerada uma das maiores e mais respeitadas ambientalista da atualidade no mundo. A exemplo da tamanha magnitude do seu trabalho, em 2012, um grupo de cidadãos da União Europeia mobilizou um milhão de europeus nesta questão e propuseram uma Lei do Ecocídio na Europa.

\subsubsection{Expectativas atuais e futuras sobre o ecocídio}

Conforme o final do item anterior, o ecocídio já é reconhecido como crime em dez países. O que é digno de nota é que, na maioria dos códigos penais que o tipificam, o crime de ecocídio está estabelecido como um "crime contra a paz", muitas vezes ao lado dos chamados quatro crimes internacionais contra a paz: crimes contra a humanidade, genocídio, 
crimes de guerra e crimes de agressão, os mesmos quatro crimes principais estabelecidos no Estatuto de Roma ${ }^{57}$. Mas por que os mesmos crimes?

Quando os crimes contra a paz foram originalmente examinados no âmbito da ONU ao longo das décadas de 1970 a 1990, muitos países estavam a favor da inclusão do ecocídio como o quinto crime contra a paz. No entanto, ele foi retirado do texto de origem do Projeto do Código de Segurança e da Paz da Humanidade, em 1996 (como já destacado nesta pesquisa). Após 11 anos de elaboração do documento, muitos países se opuseram à sua exclusão, sendo inclusive elaborado um relatório que expõe a história do que aconteceu, chamado de "Ecocide is the Missing $5^{\text {th }}$ Crime Against Peace".

Atualmente, a Organização Eradicating Ecocide (2017), publica diversas pesquisas sobre a eficácia dessas leis, e se estão sendo realizadas por advogados dentro do âmbito Internacional, chamado de "Senior Lawyers Project UK". Como resultado dessas pesquisas, já é possível concluir que embora existam leis de ecocídio em alguns países, a eficiência dessas dependem de uma série de fatores, incluindo a aplicação da lei, um judiciário independente e o respeito pelo Estado de Direito. Muitos dos países com leis nacionais de ecocídio, são classificados com alto nível de corrupção e baixo respeito pelo Estado de Direito e pela Transparência Internacional.

Conclui-se então que diante dessa realidade, para uma lei de ecocídio ser considera eficaz, deve ser implementada a nível internacional, pois a capacidade dos agentes serem processados pelo TPI ajudaria a garantir que a lei fosse efetivamente aplicada a todos os países signatários. O que falta então?

De acordo com Eradicating Ecocide (2017), é preciso que o crime de ecocídio seja considerado um crime contra a paz internacional e colocando em prática como um crime internacional de nível superior, criando assim um "dever de cuidar" legal para todos os habitantes que foram ou estão em risco de serem seriamente prejudicados, prevenindo, proibindo e antecipando-o tanto nos danos ecológicos como nos climáticos.

\footnotetext{
${ }^{57}$ ERADICATING ECOCIDE. Disponível em: http://eradicatingecocide.com. Acesso em 30 nov. 2017.
} 
No momento não há nenhuma lei que torne o ecocídio um crime internacional. $A$ iniciativa deve ser tomada por nações que são signatários do Estatuto de Roma. Atualmente, 124 Estados são signatários do Estatuto. Logo, o primeiro passo é simplesmente um ou mais Estados proporem o ecocídio como crime, onde uma vez apresentado, é possível a abertura para os demais signatários, que após a obtenção de uma maioria de 2/3, o tornaria um direito penal internacional ${ }^{58}$.

A corte do TPI apoiada pela ONU, que fica em Haia, se pronunciou sobre casos de genocídio e crimes de guerra desde que foi criada em 2002. No entanto, sempre foi fortemente criticada por sua relutância em investigar os principais crimes ambientais e culturais, que muitas vezes acontecem em tempo de paz, critica a Organização Eradicating Ecocide (2017).

Segundo a organização, como o efeito das correntes pressões no âmbito internacional sobre a criminalização do ecocídio pelo TPI, em setembro de 2016, o Procurador do Tribunal Penal Internacional, Fatou Bensouda, publicou documento chamado de "Policy Paper on Case Selection and Prioritisation" ou "Política sobre Seleção de Caso e Priorização", acolhendo expressamente as preocupações a respeito dos crime ambientais, informando que priorizará crimes que resultem em "destruição do meio ambiente", "exploração de recursos naturais" e "desapropriação ilegal" de terras.

Neste sentido, de acordo com os levantamentos realizados durante esta pesquisa, junto a fontes seguras e não midiáticas como as da Organização Eradicating Ecocide, o TPI não ampliou sua jurisdição sem prévia mudança do Estatuto de Roma, como divulgado pela mídia internacional. Mas sim, considerou uma "interpretação extensiva dos crimes contra a humanidade, ao pressupor o ecocídio, em muitos casos, causa de tanto sofrimento quanto as guerras".

Definitivamente o TPI deu um avançou considerável no caminho do reconhecimento do ecocídio como crime internacional, mas reitera-se, o TPI não estendeu

\footnotetext{
${ }^{58}$ ERADICATING ECOCIDE. Disponível em: http://eradicatingecocide.com. Acesso em 30 nov. 2017.
} 
formalmente a sua jurisdição, afirmou apenas que iria "avaliar" ofensas existentes, como crimes contra a humanidade, em um contexto mais amplo.

Tal anúncio pode sim ser considerado como uma advertência aos executivos de empresa e investidores que o ambiente não é seu "parque de recreação", sendo os impactos e destruição ambiental reconhecidos no mais alto nível da justiça criminal. A partir dessa política, os agentes do setor privado podem ser levados a julgamento por seu papel na apreensão ilegal de terras, devastando as florestas tropicais ou envenenando fontes de água, por exemplo.

É importante frisar que o novo enfoque do TPI é direcionado aos crimes que acontece a qualquer um dos 139 países que são signatários do Estatuto de Roma. Ou seja, se o agente é originário de um desses países, ou se o Conselho de Segurança das Nações Unidas refere-se um caso à um deles, esse crime deve ter ocorrido após o dia 1이일 2002 , e não ao dia 15/09/2017, data em que o TPI publicou sua nova "Política sobre Seleção de Caso e Priorização", fica a advertência da presente pesquisa.

A "Política sobre Seleção de Caso e Priorização" com divulgação no dia 15/09/2017, também lista a consideração de outros crimes, como o: tráfico de armas, tráfico de seres humanos, o terrorismo e crimes financeiros, com intuito claro de que se pretende dar mais ajuda para Estados individuais na realização de processos nacionais ${ }^{59}$.

\section{O Tribunal Penal Internacional como guardião universal dos direitos humanos e do meio ambiente no âmbito internacional}

O combate aos "crimes internacionais", ou seja, atos que atentam contra os valores basilares da conveniência internacional é o objeto deste Capítulo, pois segundo Paulo Henrique Portela (2015), o direito internacional penal busca promover a defesa da sociedade internacional, dos Estados e da dignidade da pessoa humana contra ações que possam provocar danos a bens jurídicos cuja proteção permite que a convivência internacional se desenvolva em um contexto seguro e estável, manutenindo assim a paz, a proteção dos

\footnotetext{
${ }^{59}$ ERADICATING ECOCIDE. Disponível em: http://eradicatingecocide.com. Acesso em 30 nov. 2017.
} 
direitos humanos, a preservação ambiental, dentre outros valores ${ }^{60}$, tipificados em tratados internacionais.

É válido ressaltar, ainda pelo autor, que o direito internacional penal se difere do direito penal internacional. Isto é, enquanto o objeto do direito internacional penal é o que delimita as linhas supracitadas, o objeto do direito penal internacional refere-se ao combate dos crimes ocorridos dentro de um Estado, podendo exigir a cooperação internacional de outros Estados ou organismos internacionais estabelecidos em tratados e direto interno, devido a transnacionalidade ou a necessidade de investigação internacional que os envolve. Sendo assim, de competência das autoridades estatais e dos organismos internacionais.

Do exposto, para compreender o papel do TPI este capítulo possui como trazer ao leitor o conceito e um breve histórico do direito penal internacional para que, somente assim, seja possível abordar a função, estrutura, objetivo e princípios mais importantes deste órgão internacional, considerado nesta pesquisa "como potencial guardião da proteção universal dos direitos humanos e do meio ambiente".

A partir desta compreensão, será possível apresentar as velocidades do direito penal e como os crimes de quarta velocidade se enquadram como crimes destinados ao TPI.

\subsection{Conceito do Direito Penal Internacional}

O crime internacional é definido pela Comissão Internacional da ONU como o "descumprimento, pelo Estado, de uma obrigação essencial para a salvaguarda de interesses fundamentais da sociedade internacional e cuja transgressão é, por esse motivo, reconhecida como grave pelos membros dessa coletividade" ${ }^{\prime 61}$.

No entanto, Paulo Henrique Portela (2015) complementa a definição, uma vez que a mesma não considera a personalidade internacional do indivíduo (com seus deveres que devem ser cumpridos na vida social) em harmonia com o princípio da personalidade individual, fundamental ao direito penal. Assim, os crimes internacionais são, segundo o autor, "atos cometidos por indivíduos ou por Estados, que violam princípios e regras que protegem

\footnotetext{
60 PORTELA P. H. G. Direito Internacional Público e Privado - ed. 7. Salvador: JUSPODIVM, 2015, p. 525.

${ }^{61}$ ARAÚJO L. I. A. Direito Internacional Penal. Rio de Janeiro: Forense, 2000, p. 3.
} 
valores aos quais a humanidade decidiu atribuir importância maior"'62.

\subsection{Histórico do Direito Penal Internacional}

Os crimes internacionais remontam a segunda metade do século XIX, quando uma mobilização internacional de humanização da guerra se iniciou, consolidando-se, no entanto, apenas após a Segunda Guerra Mundial, a partir da formação de um sistema internacional de proteção dos direitos humanos e de um mecanismo internacional de segurança coletiva administrada pela $\mathrm{ONU}^{63}$.

A responsabilidade pelo combate aos crimes internacionais é dever do Estado em que o ato iniciou, no entanto, esvaindo-se seus recursos internos, reitera-se a possibilidade de intervenção dos organismos intergovernamentais com poderes suficientes para estancar o ato por meio do $\mathrm{TPI}^{64}$, sejam os crimes provocados por indivíduo ou pelo Estado, o que inclui a este último, sua inércia na solução destes, há que se destacar.

2.3. O Tribunal Penal Internacional: potencial guardião da proteção universal dos direitos humanos e do meio ambiente

Órgão jurisdicional internacional voltado ao combate aos crimes internacionais, possui como precursores as cortes militares internacionais criadas por tratados após a Segunda Guerra Mundial. O objetivo dessas cortes, que não eram permanentes, era processar e julgar indivíduos, envolvidos em atos considerados como "crime de guerra", a exemplo o Tribunal de Nuremberg (criado pelo Estatuto de Londres) que julgou integrantes do governo nazista.

É válido ressaltar que conforme Paulo Henrique Portela (2015) enfatiza, à luz do princípio da responsabilidade internacional, o julgamento era sobre o individuo e não sobre as instituições, como o Estado ${ }^{65}$, como se dele e de suas ideologias não fizesse parte.

De acordo com o autor, com personalidade jurídica própria, de Direito Internacional - assim não sendo órgão da ONU e nem de qualquer outra organização

\footnotetext{
62 PORTELA P. H. G. Direito Internacional Público e Privado - ed. 7. Salvador: JUSPODIVM, 2015, p. 525.

${ }^{63}$ ARAÚJO L. I. A. Direito Internacional Penal. Rio de Janeiro: Forense, 2000, p. 3.

${ }^{64}$ PORTELA P. H. G. Direito Internacional Público e Privado - ed. 7. Salvador: JUSPODIVM, 2015, p. 526.

65 PORTELA P. H. G. Direito Internacional Público e Privado - ed. 7. Salvador: JUSPODIVM, 2015, p. 527.
} 
internacional -, o TPI foi criado em 1988, fruto do Estatuto de Roma, iniciando, porém, suas atividades somente em 2003, em Haia, sede esta localizada na Holanda. Sua principal diferença quanto as cortes internacionais anteriores, está na previsão de sua permanência, como destaca o artigo primeiro do Estatuto: "instituição permanente, com jurisdição sobre as pessoas responsáveis pelos crimes de maior gravidade com alcance internacional".

O nascimento do TPI advém da percepção histórica da humanidade, marcada por atrocidades cometidas por graves crimes que ameaçam à paz, à segurança, à estabilidade internacional, e que, ainda, maculam contra a dignidade humana ao romperem os laços existentes entre os povos ${ }^{66}$ do Planeta.

O TPI surge com intuito de contribuir, em conjunto com os Estados, no combate contra os crimes internacionais, atuando apenas em complementariedade às jurisdições penais nacionais, quando esgotado os recursos internos estatais ou quando estes se demonstrarem ineficazes ou em desconformidade com os compromissos internacionais dos Estados signatários, sendo assim considerado um Tribunal de exceção.

Em conformidade ao parágrafo 3 ㅇ do artigo 21 do Estatuto de Roma, as atividades do TPI devem estar em conformidade com os princípios que o permeia, isto é, por outros tratados e convenções que também definem os crimes internacionais, direitos humanos e os conflitos armados. Ao observar o Regulamento e o Regime do Tribunal, este pode se fundar nas normas de Direito interno dos Estados, desde que sejam compatíveis com o Direito Internacional aplicável e com o Estatuto de Roma ${ }^{67}$.

Como potencial guardião da proteção universal dos direitos humanos, o TPI ao ter como obrigação a proteção dos inúmeros valores de interesse dos indivíduos, vincula à proteção da dignidade humana e com ela os direitos humanos ${ }^{68}$ e ambientais (que à ela se integra como abordado no Capítulo anterior).

\subsubsection{Estrutura}

Com relação a sua composição, o TPI possui dezoito juízes, escolhidos a partir da da garantia da equitativa participação feminina e dos principias sistemas jurídicos do mundo.

\footnotetext{
66 Idem, Ibidem.

${ }^{67}$ BRASIL. Estatuto de Roma. Decreto no 4.388, de 25 setembro de 2002, artigo 21, parágrafo 3․ Disponível em http://www.planalto.gov.br. Acesso em 09 mar. 2018.

68 PORTELA P. H. G. Direito Internacional Público e Privado - ed. 7. Salvador: JUSPODIVM, 2015, p. 527.
} 
Os juízes selecionados, devem dominar uma das línguas de trabalho da corte que é o francês ou inglês. Devem ainda, ter reconhecida competência e experiência em matérias de competência do Tribunal, como Direito Penal, Direito Processual Penal, Direito Internacional, Direito Humanitário e Direitos Humanos ${ }^{69}$ (o que inclui o ambiental).

Como espinhal dorsal, o TPI possui como órgão: a Presidência, a qual administra os aspectos jurídicos do TPI; a Secretaria, que administra os aspectos não-judiciais, como a criação e administração de unidade de apoio às vítimas e testemunhas, a qual está subordinada à Presidência; e a Assembléia dos Estados-partes, órgão plenário do TPI onde estão representados todos os seus Estados-membros, com privilégios e imunidades suficientes ao bom andamento dos seus trabalhos, tratando, além das questões administrativas gerais, a deliberação das mudanças no Estatuto de Roma e demais instrumentos que governam a Corte ${ }^{70}$.

Possui ainda a Procuradoria, que recebe, acolhe, abre e conduz os inquéritos e ações penais sob anuência do Juízo de Instrução, basicamente; o Juízo de Instrução, que recebe as representações das vítimas (dentre outras atividades); o Juízo de Julgamento em Primeira Instância, que processa e julga a representação (dentre outras atividades); e o Juízo de Recurso, que processa e julga as apelações contra os julgados do juízo anterior e realiza as revisões ${ }^{71}$.

Os juízes, o Procurador, os Procuradores-Adjuntos e o Secretário, no exercício de suas funções, gozam de privilégios e imunidades cedidos aos chefes de missões diplomáticas ${ }^{72}$.

\subsubsection{Princípios}

Tradicionalmente, afirmam Renata Mantovani de Lima e Mariana Martins da Costa Brina (2006), os princípios são essenciais em qualquer sistema legal, uma vez que orienta a interpretação das leis quando a construção legal positiva se demonstrada insuficiente. No entanto, os indivíduos são submetidos à exclusiva jurisdição do Estado em

\footnotetext{
69 BRASIL. Estatuto de Roma. Decreto no 4.388, de 25 setembro de 2002, artigos 34 - 52. Disponível em http://www.planalto.gov.br. Acesso em 09 mar. 2018.

70 PORTELA P. H. G. Direito Internacional Público e Privado - ed. 7. Salvador: JUSPODIVM, 2015, p. 530.

${ }^{71}$ LIMA, R. M; BRINA, M. M. C. O Tribunal Penal Internacional. Belo Horizonte: DEL REY, 2006, p. 58 - 63.

72 PORTELA P. H. G. Direito Internacional Público e Privado - ed. 7. Salvador: JUSPODIVM, 2015, p. 530.
} 
que vivem, e assim, a transposição de conceitos e categorias próprios de direitos penais nacionais para o plano internacional, o que pode revelar-se problemático.

Para a solução desta celeuma, destacam as autoras, o TPI adotou princípios que guiam suas atividades a partir do previsto nos artigos 10, 13 e 20 a 33 do Estatuto de Roma, que são: responsabilidade individual, onde se julga indivíduos e não Estado (o que não exclui os crimes cometidos pelos Chefes de Estado após o dia 19/09/2002); complementariedade da jurisdição universal, atuando quando a incapacidade do Estado em que o crime estiver ocorrendo for demonstrada; Legalidade; Ne bis in idem; Irretroatividade (salvo para beneficiar o réu) e Imprescritibilidade; e a Irrelevância da qualidade oficial e os crime cometido em obediência a ordens superiores, o que não exclui, em princípio, a responsabilidade ${ }^{73}$.

É válido ressaltar que os preceitos que norteiam o TPI não se esgotam nos princípios supracitados, punindo não apenas o crime em si, mas a sua tentativa.

Os crimes de competência do TPI são de rationae materiae, ou seja, em razão da matéria, pois examina quatro tipos de crimes quando cometidos gravemente contra a comunidade internacional em seu conjunto, ensinam Renata Mantovani de Lima e Mariana Martins da Costa Brina (2006), a saber: crimes de guerra, crimes de agressão e genocídio e crimes contra a humanidade (o que inclui os crimes ambientais, dentre eles o ecocídio mesmo que sem uma previsão expressa, conforme apresentado no capítulo anterior). Todos previstos entre os artigos 5 a 8 do Estatuto de Roma ${ }^{74}$.

Nesta pesquisa, não serão abordados os crimes de crimes de guerra, os crimes de agressão e genocídio, tecendo apenas breve aprofundamento sobre os crimes contra a humanidade (o que inclui os crimes ambientais, dentre eles o ecocídio), uma vez que foi abordado seu caráter histórico no Capítulo anterior.

Diante do exposto, segundo Paulo Henrique Portela (2015), os crimes contra a humanidade são aqueles ${ }^{75}$ :

"cometidos no quadro de um ataque, generalizado ou sistemático, contra qualquer população civil havendo conhecimento desse ataque. Tais atos incluem, dentre

\footnotetext{
73 LIMA, R. M; BRINA, M. M. C. O Tribunal Penal Internacional. Belo Horizonte: DEL REY, 2006, p. 85 - 100.

${ }^{74}$ Idem, ibidem.

75 PORTELA P. H. G. Direito Internacional Público e Privado - ed. 7. Salvador: JUSPODIVM, 2015, p. 535.
} 
outros: homicídio; extermínio; escravidão; deportação ou transferência forçada de populações; prisão ou outra forma de privação de liberdade física grave, em violação das normas fundamentais de direito internacional; tortura, violação da liberdade sexual; desaparecimento forçado; perseguição de um grupo ou coletividade que possa ser identificado, por motivos políticos, raciais, nacionais, étnicos, culturais, religiosos ou de gênero; "limpeza étnica; e apartheid".

Normas que venham abranger atos não previstos no Estatuto de Roma, também devem ser considerados, como os desumanos ou de caráter semelhante, ao causarem intencionalmente grande sofrimento ou que afetem gravemente a integridade física ou a saúde física ou mental, como o terrorismo, por exemplo.

\subsubsection{Competências}

O TPI possui ainda a competência rationae loci, persone e temporis. Sobre essas competências, é notório ressaltar que a competência rationae loci do TPI, pode ser exercida no território de qualquer Estado-Parte, e por acordo especial, no território de qualquer outro Estado. O que inclui o exame, inclusive dos crimes internacionais ocorridos a bordo de navios ou aeronaves dos Estados registrados, praticados por seus nacionais. O TPI, em vista a relevância da promoção da paz e da segurança internacional, pode estender sua competência sobre territórios de Estados não-membros do Estatuto de Roma, independente de seu consentimento, desde que haja sua representação do Conselho de Segurança da ONU ${ }^{76}$.

A competência rationae persone do TPI abrange os indivíduos responsáveis pelos crimes de maior gravidade com alcance internacional e que, à data do crime, não seja o agente menor de 18 anos de idade, sendo irrelevante a sua nacionalidade. Já a competência rationae temporis do TPI, destaca Paulo Henrique Portela (2015), refere-se apenas aos atos cometidos após a entrada em vigor do Estatuto de Roma, em 2002. Para os Estados que aderiram ao Estatuto posteriormente, o TPI somente processará e julgará atos praticados após sua entrada em vigor nestes Estados ${ }^{77}$.

\subsubsection{Persecução processual}

As normas processuais do TPI estão previstas no próprio Estatuto de Roma, nos artigos 13 a 15. Tais artigos, possibilitam o exercício da jurisdição do TPI a partir do inquérito

\footnotetext{
76 PORTELA P. H. G. Direito Internacional Público e Privado - ed. 7. Salvador: JUSPODIVM, 2015, p. 535.

77 BRASIL. Estatuto de Roma. Decreto no 4.388, de 25 setembro de 2002, artigo 11. Disponível em http://www.planalto.gov.br. Acesso em 09 mar. 2018.
} 
promovido pelo seu Procurador ou por denúncias dirigidas a ele, por meio de um dos EstadosPartes ou pelo Conselho de Segurança da ONU, com previsão nos artigos 53 a $61^{78}$.

A relevância das informações do inquérito será analisada pelo Procurador que se julgar cabíveis e de competência do TPI, poderá ainda suplementá-las junto aos Estados, aos órgãos da ONU, a outras organizações internacionais intergovernamentais, a ONGs ou a outras fontes fidedignas que considerar apropriadas, podendo ainda recolher depoimentos escritos ou orais na sede do Tribunal. O Juízo de Instrução, ao autorizar a abertura do inquérito, o processo investigatório iniciará podendo o réu ser julgado de acordo com os artigos 62 a 76 do Estatuto. No entanto, caso recuse, nada impede que o Procurador formule posteriormente outro pedido com base em fatos novos ou provas referentes à mesma situação, conforme o artigo 13, parágrafo 5으 do Estatuto de Roma ${ }^{79}$.

O artigo 15, parágrafo 3o adverte que as vítimas do crime podem apenas apresentar representações ao Juízo de Instrução, não sendo acolhidas petições individuais ou de entidades, como ocorre com as ONGs. $\mathrm{O}$ artigo 16 também alerta que nenhum inquérito ou procedimento criminal poderá iniciar ou prosseguir seus termos por um período de 12 meses. No entanto, caso o pleito seja realizado pelo Conselho de Segurança da ONU, com data a contar do pedido, a aprovação deverá ser realizada por resolução aprovada nos termos do Capítulo VII da Carta das Nações Unidas ${ }^{80}$.

O Juízo de Recursos apreciará os inconformismos da sentença de julgamento do Juízo de Instrução, seja pelo Procurador ou pelo acusado. Assim, pode o Juízo de Recursos anular ou modificar sua decisão ou alterar a pena ou ordenar um novo julgamento de primeira instancia, mas sempre vedado o reformatio in pejus ${ }^{81}$.

Paulo Henrique Portela (2015) ensina que o Estatuto de Roma prevê a obrigatoriedade do pronunciamento da sentença pelo TPI, que deverá ser ou por unanimidade ou por maioria dos votos dos seus juízes do Juízo de Julgamento em Primeira Instância, proferidas em audiência pública, na presença do acusado, se assim possível.

\footnotetext{
78 Idem, Ibidem.

79 PORTELA P. H. G. Direito Internacional Público e Privado - ed. 7. Salvador: JUSPODIVM, 2015, p. 538.

80 BRASIL. Estatuto de Roma. Decreto no 4.388, de 25 setembro de 2002, artigo 11. Disponível em http://www.planalto.gov.br. Acesso em 09 mar. 2018.

${ }^{81}$ PORTELA P. H. G. Direito Internacional Público e Privado - ed. 7. Salvador: JUSPODIVM, 2015, p. 540.
} 
As penas impostas pelo TPI estão previstas entre os artigos 103 a 111 do Estatuto de Roma, havendo inclusive a possibilidade de sua redução no artigo 110. Caso seja indeferida de início, não há a exclusão da possibilidade de reexame futuro, que deverá ser periódico, de acordo com o Regulamento Processual do TPI ${ }^{82}$.

O TPI não condena seus réus à pena de morte, mas pode condená-los com prisão de até 30 anos; prisão perpétua, fundamentando-a devido ao elevado grau de ilicitude do fato e nas condições pessoais do condenado justifiquem tal punição; multa; perda de bens e produtos provenientes do crime cometido, direita ou indiretamente, sem prejuízo dos direitos de terceiros de boa-fé; e reparações em favor das vítimas do crime, como indenização, reabilitação e restituição ${ }^{83}$.

O Brasil, como parte do TPI, possui vínculo não apenas pela promulgação do Decreto $\mathrm{n}$ ㄴ 4.388/02, mas também pela previsão na Carta Magna do artigo 5ํㅜ, parágrafo 4으, já destacado no Capítulo anterior, e ainda, pela possibilidade dos movimentos da sociedade civil que podem ter repercussão no plano interno, uma vez que o artigo 5ㅇ, §2으, da Constituição Federal, faz previsão de que outros direitos e garantias expressas em tratados internacionais que a República Federativa do Brasil faça parte, podem ser utilizados como fundamentação.

No entanto, de acordo com Paulo Henrique Portela (2015) tal submissão ao TPI não impede ao Brasil a possibilidade de sua participação em processos negociadores de criação de outros tribunais internacionais nem a sua submissão a novas cortes penais internacionais que já existam ou que venham a ser criadas, seja global ou regionalmente ${ }^{84}$.

Para o autor, a cooperação do Brasil no TPI ainda gera muitas controvérsias entre a doutrina e a jurisprudência do Supremo Tribunal Federal - STF, uma vez que este segundo tipifica os atos considerados como crimes objetos de lei formal ou estrita (proveniente de ato parlamentar), o que não ocorre com o tratado ao qual o Brasil é signatário.

No entanto, destaca ainda o autor que tal controvérsia pode ser sanada com a

\footnotetext{
82 BRASIL. Estatuto de Roma. Decreto no 4.388, de 25 setembro de 2002, artigo 11. Disponível em http://www.planalto.gov.br. Acesso em 09 mar. 2018.

83 BRASIL. Estatuto de Roma. Decreto no 4.388, de 25 setembro de 2002, artigo 11. Disponível em http://www.planalto.gov.br. Acesso em 09 mar. 2018.

${ }^{84}$ PORTELA P. H. G. Direito Internacional Público e Privado - ed. 7. Salvador: JUSPODIVM, 2015, p. 542.
} 
aprovação do Projeto de Lei no 4.038, de 23/09/2008 ${ }^{85}$, que, em consulta ao site da Câmara dos Deputados, em 13/11/2017 (nove anos depois de sua proposta), ainda se encontra em processo de apreciação, obtendo como última movimentação, o requerimento de urgência para sua apreciação em 16/02/2016.

O projeto de lei supracitado, propõe a disposição sobre o crime de genocídio, definindo os crimes contra a humanidade, os crimes de guerra e os crimes contra a administração da justiça do TPI, instituindo normas processuais específicas que disponham sobre a cooperação do TPI, assim como dando outras providências.

É válido ressaltar que, mesmo que o TPI reconheça expressamente o ecocídio como crime contra a humanidade, é necessário que no Brasil internalize tal decisão por meio de lei. Isso decorre porque faz-se necessária à sua submissão à aprovação ao Congresso Nacional, conforme preconiza os artigos $49,1^{86}$ e 84 , VIII ${ }^{87}$ da Constituição Federal.

Neste sentido, ao Presidente cabe a sua celebração (o compromisso) já que é o único com competência para agir internacionalmente em nome do Estado, mas ao Congresso Nacional cabe a sua regulação por meio de ratificação ${ }^{88}$, pois não cabe ao Presidente da República o consentimento definitivo, em relação ao tratado, sem o abono do Congresso Nacional, que assenta sobre a vontade conjunta de dois poderes políticos (Câmara dos Deputados e Senado Federal) a formalização dessa decisão por meio de um decreto legislativo, promulgado pelo presidente do Senado e publicado no Diário Oficial do Senado ${ }^{89}$.

Destarte, após a regulamentação pelo Congresso Nacional do Projeto de Lei no 4.038/08, acarretaria aos crimes do Estatuto de Roma junto ao TPI um critério hierárquico semelhante às emendas constitucionais na ordem jurídica brasileira, isto é, seus respectivos crimes, o que inclui o ecocídio, passariam a ser considerados, em concordância com o

\footnotetext{
85 Idem, Ibidem, p. 543.

86 "Art. 49. É da competência exclusiva do Congresso Nacional: I - resolver definitivamente sobre tratados, acordos ou atos internacionais que acarretem encargos ou compromissos gravosos ao patrimônio nacional".

87 "Art. 84. Compete privativamente ao Presidente da República: (...) VIII - celebrar tratados, convenções e atos internacionais, sujeitos a referendo do Congresso Nacional".

${ }^{88}$ VARELA, M. D. Direito internacional público. Ed. 4 - São Paulo: Saraiva, 2012, p. 64.

${ }^{89}$ REZEK, J. F. Direito Internacional Público: curso elementar. 13 ed. rev., aumen. e atual. - São Paulo: Saraiva, 2011 , p. 88 e 89.
} 
entendimento do STF, como um tratado de hierarquia supralegal ${ }^{90}$.

\section{A morte do rio Doce, Estados de Minas Gerais e Espírito Santo, como ecocídio brasileiro}

Em 05 de novembro de 2015, no distrito de Bento Rodrigues, Município de Mariana no Estado de Minas Gerais, ocorreu o rompimento da barragem "Fundão" da mineradora brasileira SAMARCO S/A, tendo como consequência a maior tragédia socioambiental brasileira provocada pela ação humana, uma vez que destinou ao Rio Doce, localizado nos Estados de Minas Gerais e Espírito Santo, a sua morte pelos mais de 62 milhões de metros cúbicos de rejeitos de minério de ferro que percorreram cerca de $680 \mathrm{~km}$ até às regiões costeiras e marinha do oceano Atlântico (Figura 1), levando a morte de 19 pessoas, sendo uma delas até hoje desaparecida ${ }^{91}$.

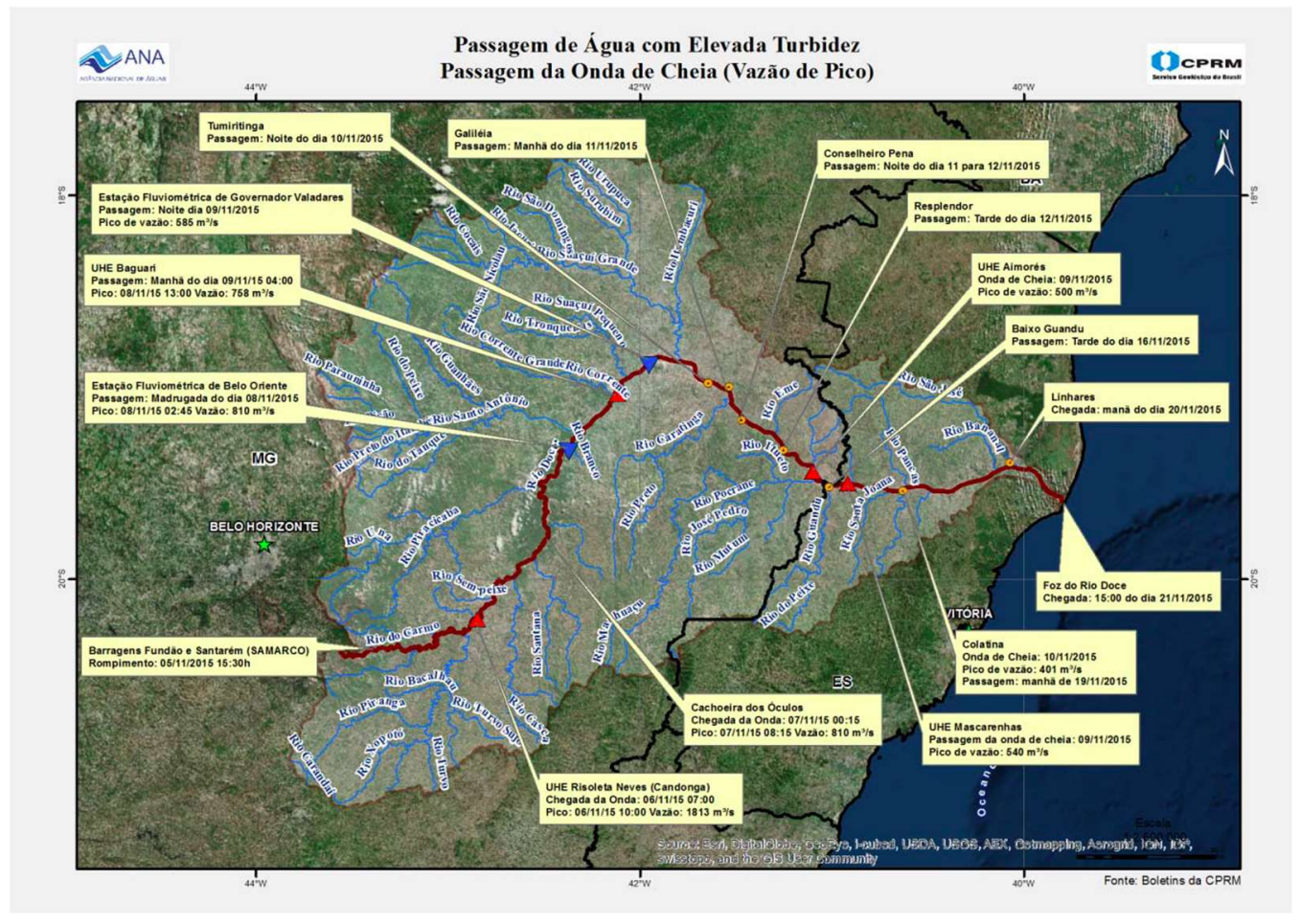

Figura 1: Cronologia da passagem do rejeito de minério de ferro desde o rompimento da barragem até o Oceano Atlântico. Fonte: Companhia de Pesquisa de Recursos Minerais (CPRM), 2016.

Destarte, a partir deste estudo de caso, propõem-se ao leitor identificar a quem

\footnotetext{
90 GONTIJO, A. P. Constitucionalismo compensatório como discurso em matéria de direitos humanos: limites e possibilidades da interação dos julgamentos da Corte Interamericana de Direitos Humanos com os Estados da América Latina. 2016, p. 244. Tese (Doutorado em Direito das Relações Internacionais) - Centro Universitário de Brasília - UNICEUB.

${ }^{91}$ MESQUITA, R. V. Lama sem fim. Revista Planeta. São Paulo, no 527, ano 43. Dez. 2016, p. 19.
} 
pertence a tutela jurídica do meio ambiente e o papel dos órgãos de fiscalização e de controle ambiental, apresentando os números alarmantes desta tragédia que é objeto deste estudo de caso dessa pesquisa, abordando breves considerações sobre o retrocesso legal diante da efetiva reparação dos danos ambientais.

3.1. A tutela jurídica do meio ambiente e o papel dos órgãos de fiscalização e de controle ambiental

A Constituição da República Federativa do Brasil de $1988^{92}$, no caput do seu artigo 225, concede a tutela jurídica do meio ambiente, igualitariamente, ao Estado e à coletividade, sendo que a Política Nacional do Meio Ambiente - PNMA, por meio da Lei no 6.938/8193, inovou ao instituir a legitimidade da defensa do meio ambiente - com a possibilidade de propositura de Ação de Responsabilidade Civil no que concerne aos danos ambientais - e a defesa dos interesses indisponíveis da sociedade e do indivíduo - por meio de Ação Civil Pública - ao Ministério Público, uma vez que regulamentou tal medida pela Lei no 7.347/8594, estendendo à coletividade o exercício desta proteção.

A PNMA, além das inovações supracitadas, com fundamento no artigo 23 , incisos VI e VII e o artigo 235 da Carta Magna, instituiu o Cadastro de Defesa Ambiental e constitui o Sistema Nacional do Meio Ambiente - SISNAMA, formado por órgãos e entidades da União, dos Estados, do Distrito Federal, dos Municípios e por Fundações instituídas pelo Poder Público, responsáveis pela proteção e melhoria da qualidade ambiental, tendo a seguinte estrutura ${ }^{95}$ : Órgão Superior: O Conselho de Governo; Órgão Consultivo e Deliberativo (Conselho Nacional do Meio Ambiente - CONAMA); Órgão Central (Ministério do Meio Ambiente - MMA); Órgão Executor (Instituto Brasileiro do Meio Ambiente e dos Recursos Naturais Renováveis - IBAMA).

\footnotetext{
92 BRASIL. Constituição da República Federativa do Brasil de 1988. Disponível em http://www.planalto.gov.br. Acesso em 09 mar. 2018.

93 BRASIL. Lei no 6.938/81 de 31 de agosto de 1981. Disponível em http://www.planalto.gov.br. Acesso em 09 mar. 2018.

${ }^{94}$ BRASIL. Lei no 7.347/85 de 24 de julho de 1985. Disponível em http://www.planalto.gov.br. Acesso em 09 mar. 2018.

95 MINISTÉRIO DO MEIO AMBIENTE. CONAMA. Sistema Nacional do Meio Ambiente - SISNAMA. Disponível em: http://www.mma.gov.br/port/conama//estr1.cfm. Acesso em 08 fev. 2018.
} 
Fazem parte ainda dessa mesma estrutura supracitada: Órgãos Seccionais (órgãos ou entidades estaduais responsáveis pela execução de programas, projetos e pelo controle e fiscalização de atividades capazes de provocar a degradação ambiental); e Órgãos Locais (órgãos ou entidades municipais, responsáveis pelo controle e fiscalização dessas atividades, nas suas respectivas jurisdições) ${ }^{96}$.

Segundo o MMA (2018), a atuação do SISNAMA ocorre mediante articulação coordenada com órgãos e entidades que o constituem, observado o acesso da opinião pública às informações relativas as agressões ao meio ambiente e às ações de proteção ambiental, na forma estabelecida pelo CONAMA; cabendo aos Estados, ao Distrito Federal e aos Municípios a regionalização das medidas emanadas do SISNAMA, elaborando normas e padrões supletivos e complementares; e aos Órgãos Seccionais, a prestação das informações sobre os seus planos de ação e programas em execução, consubstanciadas em relatórios anuais, que devem ser consolidados pelo MMA, em um relatório anual sobre a situação do meio ambiente no País, para somente assim ser publicado e submetido às considerações do CONAMA, em uma segunda reunião do ano subsequente ${ }^{97}$.

Destarte, era necessário a fixação de normas, nos termos dos incisos III, VI e VII do caput e do parágrafo único do artigo 23 da Constituição Federal, referente a cooperação entre a União, os Estados, o Distrito Federal e os Municípios nas ações administrativas decorrentes do exercício da competência comum relativas à proteção das paisagens naturais notáveis, à proteção do meio ambiente, ao combate à poluição em qualquer de suas formas e à preservação das florestas, da fauna e da flora. Assim, a Lei Complementar no 140/11 preconizou para si essa responsabilidade, bem como a alteração da Lei no 6.938/81.

Tal regulamentação esclareceu a prerrogativa de licenciamento ambiental e de fiscalização dos órgãos ambientais objetivando o equilíbrio do desenvolvimento, sem impor, limitações às competências comuns desses órgãos. A exemplo desse objetivo, há o artigo 17, §3이 da lei em tela, que traz à luz que o auto de infração emitido do órgão licenciador, bem

\footnotetext{
${ }^{96}$ MINISTÉRIO DO MEIO AMBIENTE. CONAMA. Sistema Nacional do Meio Ambiente - SISNAMA. Disponível em: http://www.mma.gov.br/port/conama//estr1.cfm. Acesso em 08 fev. 2018.

97 Idem, ibidem.

98 BRASIL. Lei Complementar no 140/11, de 08 de dezembro de 2011. Disponível em http://www.planalto.gov.br. Acesso em 09 mar. 2018.
} 
como a sua instauração de processo administrativo para a apuração de infrações à legislação ambiental cometidas pelo empreendimento ou atividade licenciada ou autorizada, não impede o exercício pelos entes federativos da atribuição comum de fiscalização da conformidade de empreendimentos e atividades efetiva ou potencialmente poluidores ou utilizadores de recursos naturais com a legislação ambiental em vigor, prevalecendo o princípio da eficiência quanto a não punição duplicada por essas esferas de uma mesma ocorrência. Assim, prevalecendo que o auto de infração ambiental seja lavrado por órgão que detenha a atribuição de licenciamento ou autorização para tal.

A Constituição Federal de 1988, no intuito de efetivar a tutela ambiental, determinou a necessidade de uma correspondente legislação protetiva, de acordo com o artigo 24, inciso $\mathrm{VI}$ e VIII, ao inserir o meio ambiente como competência legislativa concorrente dos entes da federação, propiciando uma maior abrangência protetiva, consagrando assim, segundo Celso António Pacheco Fiorillo (2011):

\footnotetext{
"uma nova e importante forma de existência de um bem que não possui características de bem público e, muito menos, privado, voltado à realidade do século XXI, das sociedades de massa, caracterizada por um crescimento desordenado e brutal avanço tecnológico. Diante desse quadro, a nossa Carta Magna estruturou uma composição para a tutela dos valores ambientais, reconhecendoIhes características próprias, desvinculadas do instituto da posse e da propriedade, consagrando uma nova concepção ligada a direito que muitas vezes transcendem a tradicional ideia dos direitos ortodoxos: os chamados direitos difusos" $"$.
}

Neste sentido, complementa o autor, a Carta Magna apresenta a tutela dos direitos ambientais baseada em um direito difuso, ao “(...) apresenta-se como um direito transindividual, tendo um objeto indivisível, titularidade indeterminada e interligada por circunstâncias de fato" 100 .

É mister ressaltar que as ferramentas jurídicas que combatem a degradação ambiental ou a iminência de um possível dano ambiental, gerados pelo homem de forma intencional ou não por inobservância das condicionantes estabelecidas pelos órgãos que compõem o Sistema Nacional do Meio Ambiente - SISNAMA e que ferem o conceito de "desenvolvimento sustentável", estão instituídas na Lei no 9.605/98. Neste sentido, Miguel Reale (1987) leciona: "se antes recorríamos à natureza para dar uma base estável ao Direito

\footnotetext{
99 FIORILLO, C. A. P. Curso de Direito Ambiental Brasileiro. 12. ed. São Paulo: Saraiva, 2011, p. 62.

${ }^{100}$ FIORILLO, C. A. P. Curso de Direito Ambiental Brasileiro. 12. ed. São Paulo: Saraiva, 2011, p. 56.
} 
e, no fundo, essa é a razão do Direito Natural, assistimos, hoje, a uma trágica inversão, sendo o homem obrigado a recorrer ao Direito para salvar a natureza que morre ${ }^{101}$.

Para Carlos Roberto Gonçalves (2011), a autora Maria Helena Diniz esclarece que a ação destruidora da natureza agravou-se neste século em razão do incontido crescimento das populações e do progresso científico e tecnológico, que permitiu ao homem a completa dominação da terra, das águas e do espaço aéreo. Ou seja, com tantas conquistas, o homem está destruindo os bens da natureza que existem para o seu bem-estar, alegria e saúde; contaminando rios, lagos, com despejos industriais, contendo resíduos da destilação do álcool, de plástico, de arsênico, de chumbo ou de outras substâncias venenosas; devastando florestas; destruindo reservas biológicas; represando rios, usando energia atômica ou nuclear ${ }^{102}$.

Neste sentido, medidas preventivas e repressivas precisam ser efetivadas por órgãos de proteção do meio ambiente com intuito de minimizar a ocorrência de dano ambiental ao ecossistema, como ensina Carlos Roberto Gonçalves (2011) $)^{103}$ ao considerar que:

\footnotetext{
"A reparação do dano ambiental pode consistir na indenização dos prejuízos, reais ou legalmente presumidos, ou na restauração do que foi poluído, destruído ou degradado. A responsabilidade do réu pode ser repressiva da lesão consumada ou preventiva de sua consumação iminente.

(...) Na questão do dano ambiental é bastante possível a previsão de reparação de um dano ainda não inteiramente realizado mas que fatalmente se produzirá, em decorrência de fatos já consumados e provados, como nas hipóteses de dano decorrente de atividades nucleares, danos à saúde e aos rios decorrentes do emprego de agrotóxicos, danos aos ecossistemas de uma região em razão do vazamento de oleoduto etc.".
}

\section{Ecocídio no Brasil: o estudo de caso na nova concepção de crime internacional contra a humanidade: utopia ou realidade?}

A efetividade na reparação dos danos resumem-se a uma tentativa frustrante de atenuar os danos ocasionados, uma vez que em março de 2016 foi assinado um acordo interfederativo pela SAMARCO S/A, suas acionistas: mineradora Vale (que é composta por

\footnotetext{
${ }^{101}$ REALE, M. Memórias. São Paulo, Saraiva, 1987, v.1, p. 297.

102 DINIZ, Maria Helena apud GONÇALVES, Carlos Roberto. Responsabilidade Civil. 13. ed. São Paulo: Saraiva, 2011, p. 116.

${ }^{103}$ GONÇALVES, Carlos Roberto. Responsabilidade Civil. 13. ed. São Paulo: Saraiva, 2011, p. 125.
} 
capital misto, provado e do governo federal) e a anglo-autraliana BHP Billion, governo federal e governos estaduais de Minas Gerais e do Espírito Santo, mas logo foi anulado três meses depois a pedido do Ministério Público Federal - MPF, por identificar irregularidades como a responsabilidade da recuperação pela fiscalização ter ficado a cargo da empresa SAMARCO S/A e por não ter ocorrido consulta prévia a população mais atingida ${ }^{104}$.

Conforme as pressões e revoltas da população foram ganhando níveis alarmantes, em agosto de 2016, a empresa SAMARCO S/A criou a Fundação Renova, que de acordo com o que foi definido no TAC, passaria a administrar $\mathrm{R} \$ 4,4$ bilhões (4 bilhões e 4 mil reais) por três anos, e ainda mais 39 projetos de reparação de danos ambientais, sociais e econômicos com ações que devem duram até 15 anos e envolver $\mathrm{R} \$ 20$ bilhões (vinte bilhões de reais), no total ${ }^{105}$.

Segundo Nota Técnica no 001/2016 do IBAMA, até 2016, 8 mil famílias foram cadastradas pela SAMARCO S/A S/A e outras 11 mil encontravam-se em análise ${ }^{106}$, sendo que 1 milhão de pessoas foram afetadas em diferentes níveis, segundo dados do Movimento dos Atingidos por Barragens (MAB). Para essas famílias já cadastradas de alguns locais atingidos, a empresa SAMARCO S/A ofereceu uma indenização de apenas $R \$ 1$ mil (mil reais), sob a condição de assinarem um contrato garantindo que não recorrerão no futuro contra a empresa ${ }^{107}$.

Diante de todos essas informações caóticas, seria coerente que a esfera federal e principalmente a estadual buscasse mecanismos para resguardar a comunidade, o meio ambiente e a administração pública de danos como esse, mas não é o que o país demostra, uma vez que o retrocesso é nitidamente evidenciado no Congresso Federal, onde caminha o Projeto de Lei n. 3.729/04 na Câmara dos Deputados (com última ação legislativa em 13/09/2017) - que dispõe sobre o licenciamento ambiental, regulamenta o inciso IV do § 10 do art. 225 da Constituição Federal, e dá outras providências; o Projeto de Lei n. 654/15 no Senado Federal (com última ação legislativa em 28/06/2017) - que dispõe sobre o

\footnotetext{
${ }^{104}$ MESQUITA, R. V. Lama sem fim. Revista Planeta. São Paulo, no 527, ano 43. Dez. 2016, p. 20. 105 Idem, Ibidem, p. 21.

106 INSTITUTO BRASILEIRO DE MEIO AMBIENTE E DOS RECURSOS NATURAIS RENOVÁVEIS. Nota Técnica no 0001/2016 - IBAMA, 2016, p. 48.

107 MESQUITA, R. V. Lama sem fim. Revista Planeta. São Paulo, no 527, ano 43. Dez. 2016, p. 22.
} 
procedimento de licenciamento ambiental especial para empreendimentos de infraestrutura considerados estratégicos e de interesse nacional; e a proposta de Emenda à Constituição 65 - que pretende simplificar o licenciamento ambiental, além de criar um novo Código de Mineração que passaria a permitir exploração minério dentro de unidade de conservação.

\subsection{Reparação dos danos?}

Em desastre com tamanha magnitude, há que se verificar se a reparação dos danos originários dele diante da população atingida, direita ou indiretamente, advém de uma ocorrência de caso fortuito ou de uma força maior em um possível pedido de indenização.

Neste sentido, é notório ressaltar que não há uma pacificação doutrinária quanto aos seus conceitos, que ora são considerados divergentes e ora são considerados sinônimos. No entanto, a imprevisibilidade é comum aos dois conceitos, mas há que serem consideradas suas distinções.

Celso Antônio Pacheco Fiorillo (2011) nos ensina que o artigo 225, § 3ํ da Constituição Federal definiu uma tríplice responsabilidade do poluidor do meio ambiente, seja ele pessoa física ou jurídica, que são: a sanção penal, por conta da chamada responsabilidade penal (ou responsabilidade criminal); a sanção administrativa, em decorrência da denominada responsabilidade administrativa; e a sanção que, didaticamente poderíamos denominar civil, em razão da responsabilidade vinculada à obrigação de reparar danos causados ao meio ambiente ${ }^{108}$.

Neste sentido, o parágrafo primeiro do seu artigo 14 da já citada Lei no 6.938/81, no que se refere à responsabilidade civil por dano ao meio ambiente, destaca a aplicação das penalidades ao infrator, por meio de apuração de responsabilidade objetiva, isto é, independentemente de culpa, diferente do que ocorreria se fosse atribuída responsabilidade subjetiva, na qual a culpa é imprescindível.

A reparação civil dos danos ambientais pode consistir em indenização dos danos causados, reais ou presumidos, ou na restauração do que foi poluído, destruído ou degradado, caso seja possível. Sendo a responsabilidade preventiva ou repressiva. E ainda, Ocorrendo lesão ao meio ambiente, surge para o causador o dever de indenizar o dano material,

108 FIORILLO, Celso Antônio Pacheco. Curso de Direito Ambiental Brasileiro. 12. ed. São Paulo: Saraiva, 2011, p. 129. 
concernente aos prejuízos patrimoniais e o dano moral, concernente aos prejuízos à personalidade ${ }^{109}$.

O crime constitui um fato típico, ou seja, consubstanciado em uma circunstância descrita na lei, antijurídico, posto que contrário ao ordenamento jurídico, e culpável, pois para que se possa imputar algum ilícito a alguém, é necessário que o mesmo tenha atuado, no mínimo, com culpa. Destarte, tais elementos, fato típico, antijurídico e culpável, constituem os chamados conceito analíticos de crime, sendo aplicável ao Direito Ambiental, quando da ocorrência do dano (infração ambiental). Entretanto, diferente da responsabilidade civil objetiva, aplicada na seara ambiental, marcada pela desnecessidade de comprovação de culpa, a responsabilidade penal ambiental é subjetiva, carecendo de tal comprovação para a sua caracterização, dada a maior gravidade da penalização ${ }^{110}$.

Quanto à distinção entre as modalidades de responsabilidade ambiental, esclarece Celso Antônio Pacheco Fiorillo (2011) $)^{111}$ :

"A distinção fundamental, trazida pelos doutrinadores, está baseada numa
sopesagem de valores, estabelecida pelo legislador, ao determinar que certo fato
fosse contemplado com uma sanção penal, enquanto outro com uma sanção civil ou
administrativa. Determinadas condutas, levando-se em conta a sua repercussão
social e a necessidade de uma intervenção mais severa do Estado, foram erigidas à
categoria de tipos penais, sancionando o agente com multas, restrições de direito ou
privação de liberdade. A penalidade da pessoa jurídica foi um dos avanços trazidos
pela Constituição Federal de 1988".

De acordo com os principais juristas do império romano do século II, que colaboraram com a formação do Digesto romano, Domicio Ulpiano e Gaio, foram responsáveis pela definição de vários conceitos do direito civil na época, incluindo a concepção de caso fortuito e da força maior.

Neste sentido, Gaio descreve força maior, em latim, assim: "vis maior est cui humana infirmitas resistire non postest", isto é, sendo aquela a que a fraqueza humana não pode resistir, ou seja, resultante da ação humana, gerando efeitos jurídicos, independente da vontade das partes. Quanto ao conceito de caso fortuito, Domicio Ulpiano assim definiu: "fortuitus casus est, qui nullo humano consilio praevideri potest", isto é, caso fortuito é aquele

\footnotetext{
${ }^{109}$ OLIVEIRA, M. V. A Tutela Jurídica do Meio Ambiente. Conteúdo Jurídico. Brasília/DF: 02 out. 2012. Disponível em http://www.conteudojuridico.com.br. Acesso em 09 mar. 2018.

110 Idem, ibidem.

111 FIORILLO, C. A. P. Curso de Direito Ambiental Brasileiro. 12. ed. São Paulo: Saraiva, 2011, p. 144.
} 
que não pode ser previsto por nenhum meio humano, ou seja, um acontecimento de ordem natural, gerando efeitos no mundo jurídico, como quedas de raio, chuva abundantes, terremotos (mas não represas construídas artificialmente) ${ }^{112}$.

No Brasil, pela divergência doutrinária existente, com intuito de sanar tal lacuna, o Superior Tribunal de Justiça - STJ manifesta seu entendimento de acordo com o caso concreto apreciado considerando suas particularidades, não se limitando em estabelecer uma distinção entre as ocorrências, e sim, a verificação de sua existência ou não in casum, possuindo entendimento unânime, de acordo com seus julgados, que em ambos os casos, a imprevisibilidade da ocorrência lhes são comuns.

112 SILVA JUNIOR, O. A. Caso Fortuito ou Força Maior? A Hermenêutica Responde. Conteúdo Jurídico, Brasília/DF: 13 out. 2009. Disponível em: http://www.conteudojuridico.com.br. Acesso em 07 mar. 2018. 


\section{METODOLOGIA}

A metodologia adotada nesta pesquisa foi doutrinária e científica nas áreas do direito penal, ambiental, humanos e internacional, promovendo um estudo interdisciplinar pautado nos pontos elencados como a origem do estudo do ecocídio no planeta, sua evolução na história da humanidade e a real situação que hoje se encontra diante do TPI, realizando o cruzamento do arcabouço teórico com o estudo de caso proposto perante os reflexos das alterações do Tratado de Roma no Decreto no 4.388, de 25/09/2002, norma legal brasileira.

A pesquisa foi realizada por um ano, por meio de uma metodologia de "pesquisa aplicada" ao adotar uma abordagem qualitativa, do tipo explicativa, tendo como procedimento técnico a pesquisa bibliográfica. Assim, doutrinadores do direitos humanos, direito internacional, direito penal e direito ambiental foram arduamente estudados, sendo possível alcançar seu objetivo proposto.

Com intuito de tornar a metodologia da pesquisa a mais didática possível, foi realizado um levantamento bibliográfico de modo analítico e ampliado, obteve-se três fases, como já apresentado na introdução desta pesquisa, sendo neste capítulo reiterado, tamanha sua importância.

A primeira fase, limitou-se no levantamento na doutrina e jurisprudência, sobre ecocídio como um crime contra a humanidade. A segunda fase, limitou-se a uma pesquisa na doutrina e jurisprudência sobre o papel do Tribunal Penal Internacional como guardião universal dos direitos humanos e do meio ambiente no âmbito internacional e levantamento sobre o estudo de caso. A terceira fase, finalmente, ocorreu junto a plataforma sucupira, que trás em seu banco de dados, todas as revistas internacionais de direito no mundo. Destas foram pesquisadas apenas as de qualidade "A1", o que totalizou 105 revistas. A partir dessa estratégia, estas foram filtradas, organizadas e acessadas uma a uma para se verificar em suas plataformas de pesquisa, as palavras-chaves: "ecocide" e "ecocídio", sendo então encontrados um total de 22 artigos científicos internacionais, pois em algumas revistas foi possível encontrar mais de um artigo, entre os anos de 1972 a 2018 (Figura 1). 
Pesquisa Científica sobre Ecocídio no Mundo entre 1972 a 2018

(Quali A1)

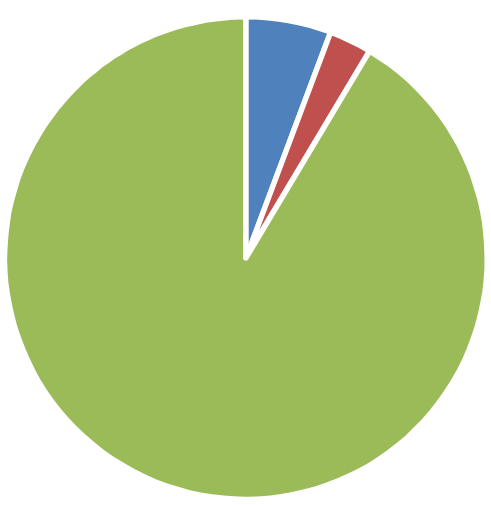

- COM ARTIGO - SEM OPÇÃO DE PESQUISA " SEM ARTIGO

Figura 2: Pesquisa Científica sobre Ecocídio no Mundo entre 1972 a 2018 (Quali A1) na Plataforma Sucupira. Fonte: autora, em 26/02/2018.

A relação estabelecida entre o arcabouço supracitado permitiu apresentar ao leitor uma discussão clara sobre os resultados da pesquisa, o que poderá ser claramente evidenciado dos capítulos a seguir. 


\section{RESULTADOS E DISCUSSÕES}

Ao longo da história do planeta, o homem é vinculado como o responsável pelos maiores desastres ambientais já registrados, que assola não apenas a flora e a fauna, mas também a todos os recursos naturais vitais para a sobrevivência de todas as espécies da Terra, como: a água, o solo e o ar.

O Brasil, diante deste cenário, com o surgimento da democrática e de uma consciência ambiental, o Estado, seja por pressão da sociedade ou por iniciativa própria, passou a adotar medidas de prevenção a acidentes e de controle para quem realiza atividades que podem trazer impacto negativo ao meio ambiente criando leis, órgãos de fiscalização e controle, incentivando a pesquisa científica, dentre outras formas.

O grande problema verificado é quando essas mesmas medidas falham e ocorrem os desastres ambientais em um país que possui uma das maiores diversidades biológicas do mundo, mas possui também uma estrutura precária de instalações e falta de manutenção constante para evitar o risco de acidentes.

Se as leis existem, não são aplicadas com severidade, seja por um paternalismo político ou por uma maior consciência por parte das empresas. Neste sentido, segundo o Portal EBC $(2015)^{113}$, os maiores desastres ambientais ocorridos no Brasil foram causados pelo homem, e a magnitude do prejuízo do dano causado, que prejudicaram a população e o meio ambiente como um todo, nunca tiveram até hoje uma punição a altura de sua consequência, isto é, com pena de prisão dos responsáveis.

De acordo com o proposto nesta pesquisa e como exemplo do exposto no parágrafo supracitado, é possível chegar ao final desta pesquisa e afirmar que o estudo de caso objeto é, sem dúvida alguma, do primeiro exemplo de ecocídio no país (mesmo diante de outros desastres já ocorrido ao longo da história ambiental brasileira), podendo, sim, ser considerado como crime contra a humanidade.

Tal afirmação é possível, pela antítese e pelo extermínio à vida, seja humana ou não, que a magnitude desta tragédia ocasionou. Consequências não só individuais, mas coletivas, prejudicaram os ecossistemas brasileiro por diversas gerações com a morte do rio

113 EBC (Portal). Relembre os principais desastres ambientais ocorridos no Brasil. Disponível em: <http://www.ebc.com.br/noticias/meio-ambiente/2015/11/conheca-os-principais-desastres-ambientaisocorridos-no-brasil>. Acesso em: 04/05/2017. 
Doce com o fim de 19 vidas inocentes, diante das decisões irresponsáveis de chefes executivos de empresas nacionais e internacionais e pela falta de efetiva fiscalização e controle do aparelho Estatal.

Em todos os aspectos, decisões equivocadas foram realizadas, o que prejudicou de forma generalizada, duradoura e permanente, não só o meio ambiente, mas a sociedade e o Planeta Terra com a violação dos direitos humanos e ambientais, uma vez que, nenhum responsável, seja empresário (responsáveis pelo dano) ou os entes do Estado (omissos no controle e fiscalização), foram efetivamente condenados (até o fechamento desta pesquisa), muito menos com sentença do cumprimento real da pena de prisão, já que o ordenamento jurídico brasileiro não possui tal previsão.

Apenas multas (algumas milionárias) foram discutidas entre as partes sem nenhuma aplicabilidade. Houve o pagamento de danos para alguns, mas ainda não são, em hipótese alguma, suficientes para reparar as vítimas e o meio ambiente brasileiro ao ponto de serem considerados protegidos.

Uma vez que o estudo de caso é exemplo de ecocídio, é possível o direito internacional preencher as lacunas do direito nacional brasileiro sobre o ocorrido. No entanto, a juridicidade do ecocídio no Brasil, só Ihe será conferida, após sua internalização por meio de lei, isto é, com a regulamentação pelo Congresso Nacional do Projeto de Lei no 4.038/08, que acarreta aos crimes previstos no Estatuto de Roma um critério hierárquico semelhante às emendas constitucionais na ordem jurídica brasileira, passando a serem considerados, como crimes também no país em concordância ao entendimento do STF, pois por constar em um tratado, passariam a ter hierarquia supralegal, podendo serem julgados como crime contra a humanidade no território brasileiro, o que inclui os ecocídios cometidos no país. 


\section{CONCLUSÕES}

É conclusivo que mesmo que o Presidente da República ao já ter promulgado o Estatuto de Roma pelo Decreto no 4.388/02 e pela previsão na Carta Magna dos § 4으 e §2으ao fazer previsão de que outros direitos e garantias expressas em tratados internacionais que a República Federativa do Brasil faça parte, possam ser utilizados como fundamentação de um possível crime de ecocídio - no artigo 5ำ, sem a regulamentação do Decreto № 4.388/02 pelo Projeto de Lei no 4.038/08, não é possível levar ao TPI os responsáveis pela morte do rio Doce, pois os crimes previstos no Estatuto de Roma não teriam um critério hierárquico semelhante às emendas constitucionais na ordem jurídica brasileira, não lhe conferindo nem no país, nem fora dele, uma hierarquia supralegal. Ou seja, na atualidade é uma utopia tal aplicabilidade.

No momento em que o Projeto de Lei no 4.038/08 for regulamentado pelo Congresso Nacional, o que esta pesquisa critica duramente ao constar-se a inércia do Estado brasileiro diante da necessidade do andamento de julgamento processual e na efetiva punição dos responsáveis por crimes de ecocídio no Brasil, será possível o encaminhamento desses responsáveis ao TPI, atendendo ao que determina o artigo 15 e 16 do Estatuto de Roma, passando o TPI a ser guardião da proteção universal dos direitos humanos e do meio ambiente brasileiro. Isto é, uma realidade possível de ser alcançada.

O que a pesquisa constata e faz alusão ao posicionamento as palavras da pesquisadora DELMAS-MARTY, M. $(2014)^{114}$ é que o ordenamento jurídico X a política brasileira necessita de uma profunda "renovação dos valores essenciais, cuja violação gera uma reprovação social". Para o pesquisador MARTIN-CHENUT, K., et. al. $(2015)^{115}$, tal renovação justifica-se pela necessidade da consagração, em direito internacional, de uma proteção penal do meio ambiente, sobretudo em virtude da disparidade das disposições nacionais e internacionais existentes visando reprimir a criminalidade ambiental. Uma discussão mais profunda que necessita de ações efetivas por parte da sociedade, a iniciar por

\footnotetext{
114 DELMAS-MARTY, Mireille. Perspectives ouvertes par le droit de l'environnement. Revue Juridique L'Environnement, Paris, v. 39, p. 7-13, 2014. Numéro spécial: Le droit répressif: quelles perspectives pour le droit de l'environnement. p. 7.

115 MARTIN-CHENUT, Kathia; NEYRET, Laurent,; PERRUSO, Camila. Rumo à internacionalização da proteção penal do meio ambiente: dos ecocrimes ao ecocídio. Revista de Direito Internacional, Brasília, v. 12, n. 2, 2015 p. $540-$ 569.
} 
que elege como seus representantes, e ainda, não menos importante, pela sua submissão ao que as leis Ihes impõe, esquecendo ela que é a ferramenta mais importante de uma democracia. 


\section{REFERÊNCIAS}

ARAÚJO L. I. A. Direito Internacional Penal. Rio de Janeiro: Forense, 2000.

BRASIL. Constituição da República Federativa do Brasil de 1988. Disponível em http://www.planalto.gov.br. Acesso em 09 mar. 2018.

BRASIL. Estatuto de Roma. Decreto no 4.388, de 25 setembro de 2002. Disponível em http://www.planalto.gov.br. Acesso em 09 mar. 2018.

BRASIL. Lei no 6.938/81 de 31 de agosto de 1981. Disponível em http://www.planalto.gov.br. Acesso em 09 mar. 2018.

BRASIL. Lei no 7.347/85 de 24 de julho de 1985. Disponível em http://www.planalto.gov.br. Acesso em 09 mar. 2018.

BRASIL. Lei Complementar no 140/11, de 08 de dezembro de 2011. Disponível em http://www.planalto.gov.br. Acesso em 09 mar. 2018.

DELMAS-MARTY, Mireille. Perspectives ouvertes par le droit de l'environnement. Revue Juridique L'Environnement, Paris, v. 39, p. 7-13, 2014. Numéro spécial: Le droit répressif: quelles perspectives pour le droit de l'environnement. p. 7.

DINIZ, Maria Helena apud GONÇALVES, Carlos Roberto. Responsabilidade Civil. 13. ed. São Paulo: Saraiva, 2011.

EBC (Portal). Relembre os principais desastres ambientais ocorridos no Brasil. Disponível em: $<$ http://www.ebc.com.br/noticias/meio-ambiente/2015/11/conheca-os-principaisdesastres-ambientais-ocorridos-no-brasil>. Acesso em: 04/05/2017.

FIORILLO, C. A. P. Curso de Direito Ambiental Brasileiro. 12. ed. São Paulo: Saraiva, 2011.

FALK, R. A. Guerra Ambiental e Ecocídio - Factos, avaliação e propostas, vol. 1 - Deepdyve: Boletim de propostas de paz, 1973.

GONÇALVES, Carlos Roberto. Responsabilidade Civil. 13. ed. São Paulo: Saraiva, 2011.

ERADICATING ECOCIDE. Disponível em: http://eradicatingecocide.com. Acesso em 12 nov. 2017.

FIORILLO, C. A. P. Curso de Direito Ambiental Brasileiro. 12. ed. São Paulo: Saraiva, 2011.

GONTIJO, A. P. Constitucionalismo compensatório como discurso em matéria de direitos humanos: limites e possibilidades da interação dos julgamentos da Corte Interamericana de Direitos Humanos com os Estados da América Latina. 2016, p. 244. Tese (Doutorado em Direito das Relações Internacionais) - Centro Universitário de Brasília - UNICEUB.

HIGGINS, P. Eradicating Ecocide: Law and Governance to Stop the Destruction of the Planet. Shepheard-Walwyn: Londres, 2010.

INSTITUTO BRASILEIRO DE MEIO AMBIENTE E DOS RECURSOS NATURAIS RENOVÁVEIS. Nota Técnica no 0001/2016 - IBAMA, 2016, p. 48.

LIMA, R. M; BRINA, M. M. C. O Tribunal Penal Internacional. Belo Horizonte: DEL REY, 2006.

MARTIN-CHENUT, Kathia; NEYRET, Laurent,; PERRUSO, Camila. Rumo à internacionalização da proteção penal do meio ambiente: dos ecocrimes ao ecocídio. Revista de Direito Internacional, Brasília, v. 12, n. 2, 2015 p. 540-569. 
MAZZUOLI, V. O. Direito Internacional Público: parte geral - ed. 8.: São Paulo: RT, 2014.

MESQUITA, R. V. Lama sem fim. Revista Planeta. São Paulo, no 527, ano 43. Dez. 2016.

MEGRET, F. O caso para um crime Geral Internacional Contra o Meio Ambiente. SSRN's: 2010.

MILARÉ E. Direito do Ambiente - ed. 5. São Paulo: Revista dos Tribunais, 2007.

MINISTÉRIO DO MEIO AMBIENTE. CONAMA. Sistema Nacional do Meio Ambiente - SISNAMA. Disponível em: http://www.mma.gov.br/port/conama//estr1.cfm. Acesso em 08 fev. 2018.

OLIVEIRA, M. V. A Tutela Jurídica do Meio Ambiente. Conteúdo Jurídico. Brasília/DF: 02 out. 2012. Disponível em http://www.conteudojuridico.com.br. Acesso em 09 mar. 2018.

PACCIOLY, H.; SILVA, G. E. N. M.; CASELA, P. B. Manual de Direito Internacional Público - ed. 23. SAVAIVA, 2017.

PORTELA P. H. G. Direito Internacional Público e Privado - ed. 7. Salvador: JUSPODIVM, 2015. REALE, M. Memórias. São Paulo, Saraiva, 1987, v.1.

REZEK, J. F. Direito Internacional Público: curso elementar. 13 ed. rev., aumen. e atual. - São Paulo: Saraiva, 2011.

SILVA JUNIOR, O. A. Caso Fortuito ou Força Maior? A Hermenêutica Responde. Conteúdo Jurídico, Brasília/DF: 13 out. 2009. Disponível em: http://www.conteudojuridico.com.br. Acesso em 07 mar. 2018.

SOARES, G. F. S. Direito Internacional Público. São Paulo: Atlas, 2002.

SOARES, G. F. S. A proteção internacional do meio ambiente. Série entender o mundo - vol. 2. São Paulo: Manole, 2005.

TOMUSCHAT, C. YEARBOOK. v. 2, 1996.

THOMÉ R. F. da S. Manual de Direito Ambiental - ed. 6. Salvador: JUSPODIVM, 2016.

UNITED NATIONS PUBLICATION. Yarbook of the International Law Commission. v. 1, 1987.

UNITED NATIONS PUBLICATION. Yarbook of the International Law Commission - v. 2, primeira parte, 1993.

VARELA, Marcelo D. Direito internacional público. Ed. 4 - São Paulo: Saraiva, 2012.

WHITAKER, B. Revised and updated report on the question of the prevention and punishment of the crime of genocide. Thirty-eighth session, Item 4 of the provisional agenda, E/CN.4/Sub.2/1985/6, 1985. 